\title{
Article \\ FIRELAN-An Ecologically Based Planning Model towards a Fire Resilient and Sustainable Landscape. A Case Study in Center Region of Portugal
}

\author{
Manuela R. Magalhães, Natália S. Cunha *(D), Selma B. Pena (D) and Ana Müller \\ Linking Landscape, Environment, Agriculture and Food (LEAF), Instituto Superior de Agronomia, \\ Universidade de Lisboa, Tapada da Ajuda, 1349-017 Lisboa, Portugal; mmagalha@isa.ulisboa.pt (M.R.M.); \\ selmapena@isa.ulisboa.pt (S.B.P.); anamuller@isa.ulisboa.pt (A.M.) \\ * Correspondence: natcunha@isa.ulisboa.pt; Tel.: +351-21-365-3314
}

Citation: Magalhães, M.R.; Cunha, N.S.; Pena, S.B.; Müller, A. FIRELAN-An Ecologically Based Planning Model towards a Fire Resilient and Sustainable Landscape. A Case Study in Center Region of Portugal. Sustainability 2021, 13, 7055. https://doi.org/10.3390/su13137055

Academic Editor: Jakub Brom

Received: 31 May 2021

Accepted: 20 June 2021

Published: 23 June 2021

Publisher's Note: MDPI stays neutral with regard to jurisdictional claims in published maps and institutional affiliations.

Copyright: (c) 2021 by the authors. Licensee MDPI, Basel, Switzerland. This article is an open access article distributed under the terms and conditions of the Creative Commons Attribution (CC BY) license (https:// creativecommons.org/licenses/by/ $4.0 /)$.
Abstract: This paper explores the role of landscape planning as a tool for rural fire prevention. It presents a methodology for a fire resilient and sustainable landscape model (FIRELAN) that articulates the ecological and cultural components in a suitable and multifunction land-use plan. FIRELAN is a conceptual and ecologically based model that recognizes river basin' land morphology, microclimate and species combustibility as the fundamental factors that determine fire behavior and landscape resilience, along with the ecological network (EN) for achieving ecological sustainability of the landscape. The model is constituted by the FIRELAN Network and the Complementary Areas. This network ensures the effectiveness of discontinuities in the landscape with less combustible landuses. It also functions as a fire-retardant technique and protection of wildland-urban interface (WUI). This model is applied to municipalities from Portugal's center region, a simplified landscape severely damaged by recurrent rural fires. The results show that land-use and tree species composition should change drastically, whereas about $72 \%$ of the case study needs transformation actions. This requires a significant increase of native or archaeophytes species, agricultural areas, landscape discontinuities and the restoration of biodiversity in Natura 2000 areas. The EN components are $79 \%$ of the FIRELAN $\mathrm{N}$ area, whose implementation ensures soil and water conservation, biodiversity and habitats. This paper contributes to the discussion of the Portuguese rural fires planning framework.

Keywords: fire prevention model; rural sustainable landscape; ecological network; land-use planning; resilient forest; Portugal

\section{Introduction}

Large-scale rural fires are a worldwide problem that has been studied in the most fire-prone regions of the world, such as North America [1], Australia [2] and Europe [3], with several methodological approaches [4]. In Europe, the Mediterranean region has been the most affected area by rural fires in the last decades [5]. In 1992, the EU forest policy agenda placed forest fire protection as a priority and identified Mediterranean countries as having high fire risk landscapes [6]. The EU Forestry Strategy of 1998 [7] and the EU 2006' Forest Action Plan (2007-2011) [8] aimed to optimize the multifunctional role of the forest through the implementation of forest fire protection plans. Even though these strategy principles were still valid, the 2013 EU Forest Strategy settled for a more coherent and proactive approach to forest policy [9]. Furthermore, as a goal from the 2030 Agenda for a Sustainable Development [10], these policies are foreseen under the European Green Deal [11] and the European Biodiversity Strategy for 2030 [12] to evolve into more effective forest preservation and restoration in Europe.

Even though the European statistics show that the average burnt area in Europe decreased in the last 35 years [13], suggesting that policies and measures related to fire prevention and suppression have been efficient, Portugal presented opposite indicators [14]. 
It is the country most affected by rural fires in Europe [15], with severe ecological damage and a tremendous impact on roads, communication lines, buildings and on human lives. In Portugal, the burnt area in 2017 was 540,630 ha with 21,002 occurrences [16], representing an area five times larger than the average of the previous ten years [17]. Due to this catastrophic situation and the continuous rise of wildfire risk, there is a consensus on seeing the fire problem as a national priority [18].

\section{The Portuguese Rural Fire Context}

The increased presence of rural fires can be attributed to the transformation and simplification of the Portuguese landscape in the XX century [19]. The chemical-mechanical paradigm led to the ongoing changes in land-use, namely afforestation and rural abandonment [15]. The traditional Portuguese rural landscape was multifunctional, integrating agriculture (Ager), extensive shrublands (Saltus) and native forestlands (Silva) in a complementary schema of natural resources exploration [19]. In that type of landscape, the rural fires had smaller dimensions and were extinguished promptly by the local population and voluntary firefighters. However, the land cover has progressively changed to even-aged stands of fast-growing species, giving rise to extensive monoculture landscapes, in a first phase (mid-19th century) with Pinus pinaster Aiton. ( $P p)$ and later (since the 1950s of the XXth century) with Eucalyptus globulus Labill. (Eg). Consequently, the economic shift towards industrialization led to the rural exodus and the expansion of unmanaged or abandoned land [20]. These events eventually prompted the beginning of large fires in Portugal, particularly since the 80s [21]. Still, in 2020 Portugal is mainly occupied by 3056 million ha (27.7\% of the country) of high-density stands of $P p(9.25 \%)$ and $E g(8.41 \%)$ and shrubs (10.04\%) [22].

Portugal presents large climatic variability between the North and South Tagus regions. The annual average rainfall varies from over $2000 \mathrm{~mm}$ in the northern mountains to $400 \mathrm{~mm}$ in southeast Algarve. With a warmer and drier climate, the Southern region is dominated by Quercus suber L. and Quercus rotundifolia Lam. Despite the South climate conditions being more favorable to fire occurrence, the North region displays most fire occurrences and concomitantly the $E g$ and $P p$ are the dominant species [22]. Therefore, this indicates that land-use and land cover are major factors in fire risk increase. Furthermore, in the southern region, whenever $E g$ is planted intensively, fires in those areas become more intense and disastrous, as happened in Serra de Monchique in the Algarve region with an estimated burnt area of around 28,000 ha by the 2018 fire [23].

In Portugal, after the Liberal Revolution in 1820, the "Administração Geral das Matas do Reino" (Permit of 24 July 1824) was created for the conservation and management of forest areas. Since then and throughout the XXth century, Portugal had a significant policy framework regarding the forest. Concerning rural fires, the national system for forest fire protection was established in 2006 (Decree-Law 124/ 2006 of 28 June), including the definition of fuel management criteria, recently revised by the Decree-Law 10/2018 of 14 February. As the first decree mentions, rural fires problem must be tackled with structural prevention measures. These measures are mainly related to the reorganization of the existing landscape. Therefore, these ideas overtake a purely economist perspective of the landscape and surpass reductive benefit accounts associated with timber and paper pulp production ( $P p$ and $E g$ ) and their impact on gross domestic product (GDP), exports and public deficit. Despite the public policies stated the intention to change, the measures application in the territory has occurred in reverse, maintaining the economist perspective.

In addition to forest general regulation at the national level, the Portuguese planning system also includes forest fire protection plans at regional, municipal and local scales. However, those plans represent a complex regulatory framework without criteria and scale integration, simultaneously with negative consequences in forest governance efficiency [24]. The revision of the regional forest landscape plans (PROF) in 2019 represented an opportunity to tackle the paradigm shift towards a structural transformation in the land-use planning system, including new targets to fire resilient landscapes, tree 
species and other sustainable land-uses. However, the revised plans still consider a policy target for 2050 with a dominant and high $P p$ and $E g$ forest cover area, representing between $60 \%$ and $90 \%$ of the total forest area [25].

Despite the Portuguese forest legislation, a full understanding of rural fire prevention through an integrated and ecologically based planning approach is still to be addressed. This approach should include both sustainable uses of the land and well-defined management measures. In this regard, the forest is of vital importance at the landscape scale, in which planning and management integration is fundamental for achieving a fire resilient and sustainable landscape. This goal goes far beyond getting tradable goods of materials and energy. It includes other ecosystem services provided by the forest, namely water quality, soil and biodiversity conservation and climate regulation. In addition, it provides immaterial services such as human contact with nature, recreation and leisure. Forest services' availability depends on forest planning and management, in order to avoid and prevent uncontrollable fires.

This paper aims to present a methodology for an ecologically based land-use planning model, that articulates the ecological and the cultural components in a suitable and multifunction land-use plan, towards a fire resilient and sustainable landscape (FIRELAN). This fire prevention model is applied to the municipalities of Pedrógão Grande, Castanheira de Pêra e Figueiró dos Vinhos, in the center region of mainland Portugal, where landscape simplification and transformation was very significant and megafires often occur. Furthermore, the FIRELAN maps will be compared with Figueiró dos Vinhos municipality's current land-use plans, namely the regional forest land-use plan [26], the municipal land-use plan $(\mathrm{PDM})$ and the municipal fire protection plan (PMDFCI).

\section{Theoretical Framework}

Research on rural fire focus more on describing the specific processes and components of fire behavior and regime, rather than integrating them into fire prevention models. This section attempts to bring together sectoral perspectives, to develop an integrative, fire resilient and sustainable, conceptual model, namely.

\subsection{Landscape Fire Resilience}

The concept of resilience is the capacity of systems to reorganize and recover from change and disturbance without changing to other states [27-29]. This concept linked with the comprehension of the landscape as a system [30] leads to the definition of landscape fire resilience as the capacity of landscape in absorbing the disturbance caused by rural fires without losing its function, structure and identity and ultimately weakening fire frequency and intensity or magnitude. The landscape fire resilience is determined by several factors related to (1) fire behavior; (2) flammability of tree species; (3) landscape discontinuities; and (4) wildland-urban interface.

\subsubsection{Fire Behavior}

Fire behavior depends on climatic factors, e.g., temperature, precipitation and wind, combined with other biophysical factors related to the river basin morphology, including slope, aspect and altitude [31-33]. Even though changes in weather conditions can lead to unpredictable fire behavior [34], the biophysical factors can contribute, to some extent, to the reduction of fire risk and, therefore, should be taken into account in land-use planning, namely:

- North aspect hillslopes, with a slope higher than $25 \%$, by receiving less radiation throughout the year, burn less than the other hillslope aspects [35].

- The fire progression speed doubles for every $10^{\circ}$ (about $17 \%$ ) increase in slope, and it can rise continuously in steep hillslopes from bottom to ridge, by approximately 5-6 $\mathrm{Km} / \mathrm{h}$ of fire speed [36].

- Above slopes higher than $30^{\circ}(57 \%)$, the relationship between the slope and fire speed is almost exponential [37]. 
- When the fire reaches the top of the river basin (ridge) if it does not progress to the opposite side due to the hillside breeze, it begins to plow along the contour lines losing speed.

\subsubsection{Flammability of Tree Species}

The post-fire observation shows that tree species do not burn equally. Specifically, native species burn less than $E g$ and $P p$, and regenerate better even in severe fire circumstances. These assumptions are substantiated by several studies [38,39]. Furthermore, regarding fire proneness, Silva et al. [40] verified a tendency in different forest types, in decreasing order: maritime pine forests, eucalyptus forests, unspecified hardwood forests, unspecified coniferous forests, cork oak, chestnut and holm oak forests. Calviño-Cancela et al. [39] state that native species are more resistant to fire than those introduced. Moreover, in the USA even trees, such as native oak trees, have been replaced by acer, poplar and beech, as they are more resistant to fire with less flammability due to their higher rate of litter decomposition [38]. In the same way, Pereira et al. [41] affirmed that there are various degrees of fire risk according to different land-uses, e.g., agricultural fields, pastures and, ultimately, spaces without shrubs or tree vegetation decrease fire risk. However, these last situations must be avoided, and covered with permanent herbaceous to prevent soil erosion. Based on the several post-fire evidence, a diversified landscape is more resilient to fire than a monoculture landscape of fast-growing tree species.

\subsubsection{Landscape Discontinuities}

Aiming for an improvement of fire prevention characteristics of landscapes, several authors [42-44] justify the need to have landscape discontinuities with several types of land-uses and fuel break networks, among others:

- Agee et al. [45] propose wide areas of shaded fuel-breaks networks covered with low-fuel vegetation areas, coupled with fuel control strips. Furthermore, the Forestry Commission Practice Guide (2014) [46] highlighted two types of fire-resistant networks in the landscape: the "firebreaks" without vegetation and "fire-belts" with broadleaved trees, which can occur separately or combined.

- According to Dickinson et al. [38], the streams and valley bottoms play a fundamental role in establishing landscape discontinuities. From a river basin perspective, these two landscape components are more crucial to reduce the size and intensity of the fire than ridges or hilltops.

- Heyerdahl et al. [33] point to the necessity of introducing fire retardant strips along the contour lines when the hillside is too long to avoid top-down and down-up fire;

- Swales or infiltration ditches, constructed along the contour lines with a berm downslope planted with native broadleaf trees and associated ponds [47] can function as linear fire-belts. These structures also reduce soil loss by erosion and increase the water basin's total water flow through infiltration.

- The mulching technique is a way to increase soil and water conservation and reduce post-fire consequences. This technique helps to increase water infiltration and retention in the soil, leading to lower species combustibility, along with a reduction in soil erosion $[48,49]$.

\subsubsection{Wildland-Urban Interface}

The wildland-urban interface (WUI) is an area of transition between wildland and urban agglomeration, in or adjacent to wildfire prone areas, with a high vulnerability and wildfire risk [50]. Mapping and evaluating WUI areas are fundamental to develop strategies to reduce fire risk [51], as several authors [52,53] refer to the need to maintain a clean strip of combustible material in the surroundings of settlements $(100 \mathrm{~m})$ or near isolated buildings (up to $30 \mathrm{~m}$ ). 


\subsection{Ecological Sustainability}

Ecological sustainability is a broad concept that ensures landscape ecological quality $[54,55]$. This concept is closely related to the capacity of landscape adaptability and resilience. In this study work, ecological sustainability is regarded as a landscape quality dependent on the value and conservation of the natural resources. It is synthesized in an ecological network and dependent on the most adequate land-uses, set by ecological land suitability assessment.

\subsubsection{Ecological Network}

The Ecological Network (EN) is recognized as a system of landscape structures or ecosystems [56,57] that provides the necessary physical and biological conditions for maintaining or restoring ecological sustainability, connectivity and biodiversity. Therefore, the EN components correspond to highly valuable ecosystems, which represent specific ecological functions, directly influenced by hydrologic availability, soil genesis processes and fertility, plant biodiversity (species), habitat resources and climate [58]. The EN mapping is rooted in landscape ecology theory [57,59-63]. The EN was mapped for mainland Portugal $[58,64]$, covering several planning scales. In this context, the Ecological Network (EN) assumes a holistic view of land use planning and biodiversity conservation and constitutes the core of the broader Green Infrastructure (GI) framework $[65,66]$ and a planning tool that supports the European Biodiversity Strategy 2030 [8].

\subsubsection{Ecological Land Suitability}

The Food and Agriculture Organization [67] defines land suitability as the fitness of a given type of land for a determined use. The earliest application of this concept was from the American landscape architects, e.g., Jacqueline Tyrwhitt, Philip Lewis, in the late nineteenth and early twentieth-century using hand-drawn overlays to locate territories suitable for future construction [68]. The land-use suitability analysis using this overlay technique has been applied by different authors, such as McHarg [59] who used ecological inventory as criteria to map the best land use and recently applied with geographical information systems (GIS) tools in several contexts.

Based on the same technique, the ecological land suitability analysis considers the abiotic and biotic characteristics thresholds for each land use. This analysis allows more careful land-use planning under the resilience of the landscape to support it. By applying this analysis at the national level, Magalhães [69] concluded that $22 \%$ of the Portuguese territory is suitable for agriculture. Still almost half of it is covered with other landuses. Moreover, about one-third of the Portugal area is ideal for conservation forest but is occupied by exotic species. This analysis also identifies the potential for expanding different species, such as cork oak, holm oak, carob and chestnut.

The proposed model considers land-use planning as a tool that integrates the above perspectives of landscape fire resilience and ecological sustainability, into a spatial framework.

\section{Case Study}

The study area is located in the Central Region of mainland Portugal (Figure 1A). It includes three contiguous municipalities (Figure 1B), Castanheira de Pêra, Pedrógão Grande and Figueiró dos Vinhos, with a very high risk of rural fire [70]. This area was devastated by the 2017 megafires, with a 25 thousand hectare burnt area [71], corresponding to $67 \%$ of the case study area. Narrow valleys and steep slopes characterize this area of $369 \mathrm{~km}^{2}$. Before the 2017 fire was densely occupied by Pinus pinaster and Eucalyptus globulus, covering $73 \%$ of the total area, (Figure 1C). The Northern area includes Serra da Lousã as part of the Natura 2000 network site (PTCON0060) dominated by Quercus rotundifolia, Quercus robur L. and Quercus pyrenaica Willd. 

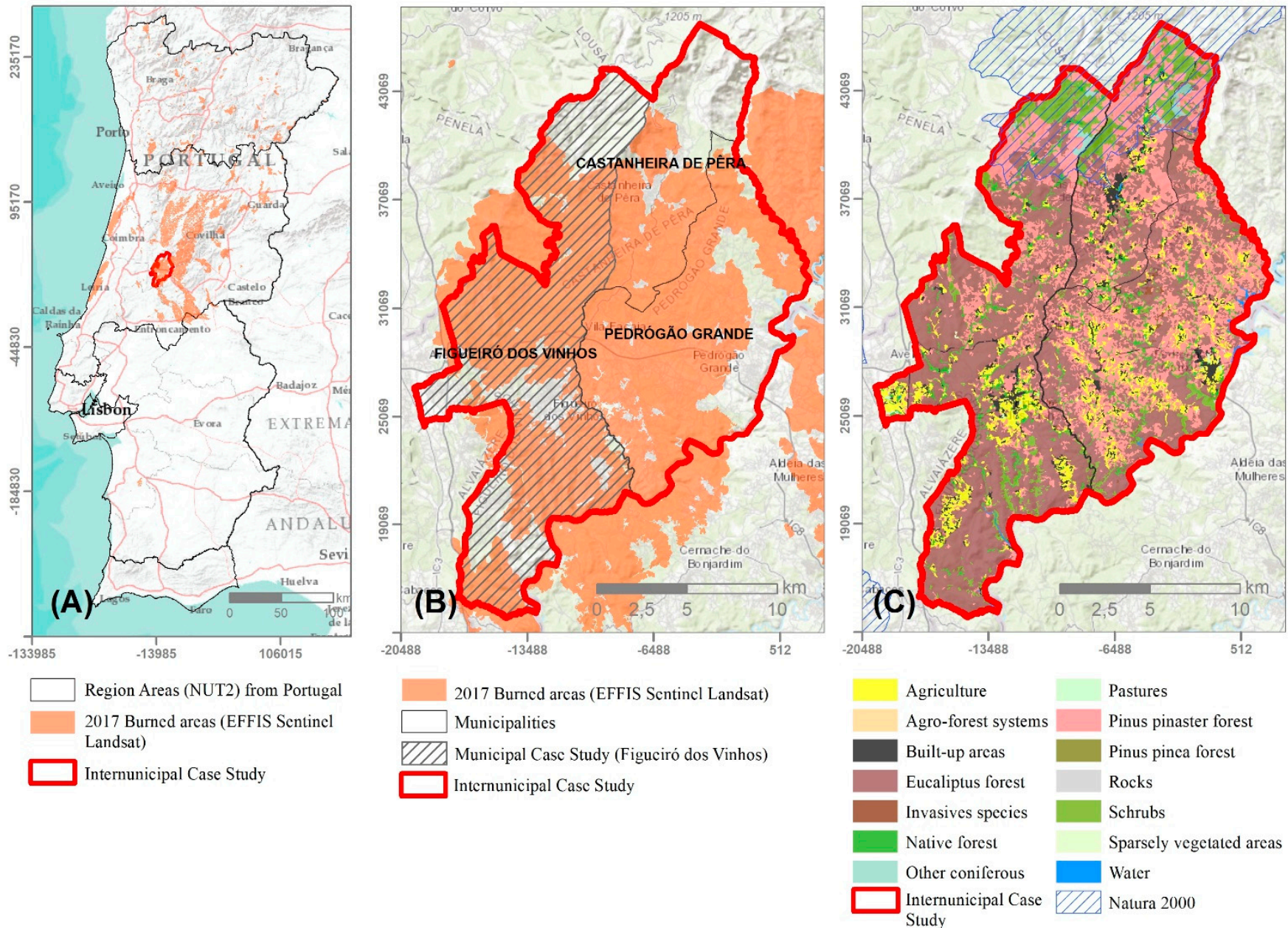

Figure 1. (A) Location of the inter-municipal case study in the mainland Portugal and center region; (B) Burnt areas by the 2017 megafires [19]; (C) The Land Use and Land Cover Map with simplified classes [18] and Natura 2000.

\section{Forest and Fire Planning Framework}

The forest and fire planning framework is analyzed only for Figueiró dos Vinhos Municipality given the other two municipalities' lack of data. The extract of the Coastal Centre Regional Forest Landscape Plan [26] for Figueiró dos Vinhos municipality (Figure 2A) presents an ecological corridor designed as a macro reference for increasing biodiversity and a priority network for fire protection. In the PROF-CL [26] the sensitive forestry areas are classified as having high and very high fire risk. The species recommended to those areas are Quercus robur L.; Quercus faginea Lam.; Eucalyptus globulus; Arbutus unedo L.; Pinus pinaster; Pinus pinea L.; Quercus suber; Quercus rotundifolia; Quercus pyrenaica; Castanea sativa Mill.; Cupressus lusitanica Mill.; Prunus avium L.; Cupressus sempervirens L.; Juglans regia L.; Juglans nigra L.; Pseudotsuga menziesii Mirb. The PROF-CL [26] also indicates that the Eucalyptus globulus $(E g)$ area should not exceed 7500 ha, representing $43 \%$ of Figueiró dos Vinhos municipality. However, according to the current Land Use and land cover map [22] eucalyptus covers 9862 ha, about $57 \%$ of the municipality area. The 2015 Figueiró dos Vinhos municipal's land-use plan (Figure 2B) indicates that "forest conservation" class, defined as areas where native species must be planted, and fast-growing species afforestation are prohibited, should cover more than $50 \%$ of the municipal area. However, the land use and land cover map [22] shows that in 2018 native species area corresponds only to $5.5 \%$ of the municipality.

The fire protection Municipal plan [72] is a legal response, at a local scale, to the National fire forest protection system. This plan proposes the implementation of: (i) Networks of fuel management (primary and secondary), (ii) Mosaics plots of fuel management, in 
particular, settlements protection buffer $(100 \mathrm{~m})$, forest road buffer with a width not less than $10 \mathrm{~m}$, transmission lines and distribution of electricity protection buffer (Figure 2C); (iii) network of water points; (iv) Preventive forestry recommendations and (v) post-fire measures. In addition to these fire protection measures, namely fuel management lines and buffer areas, the PDMFCI does not include any recommendation or spatial proposal relative to fire-adapted species or resilient land-uses, or even forest discontinuity and associated landscape diversification. This fire protection plan indicates that this competence is part of land use plans [73].

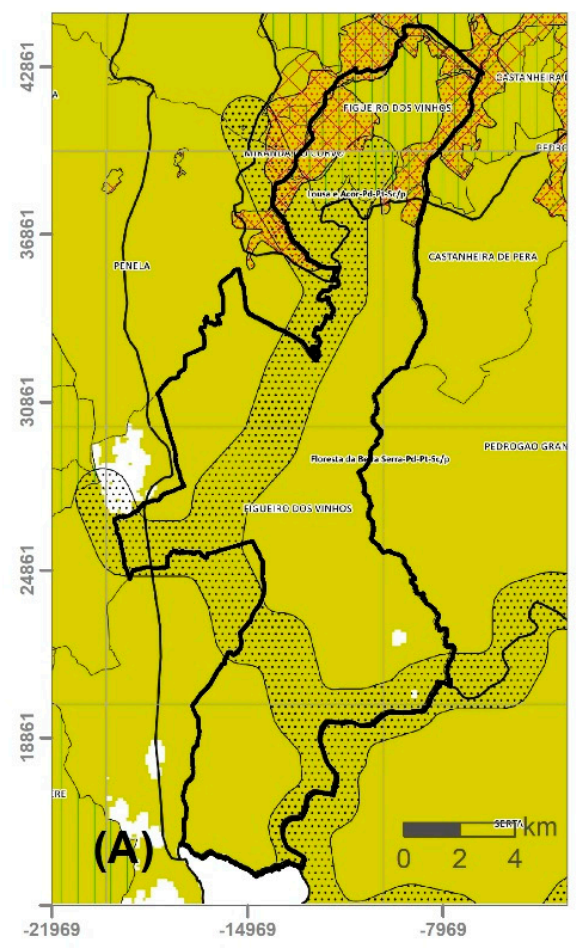

PROF

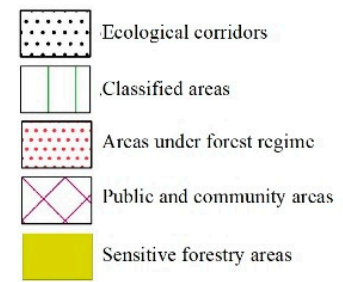

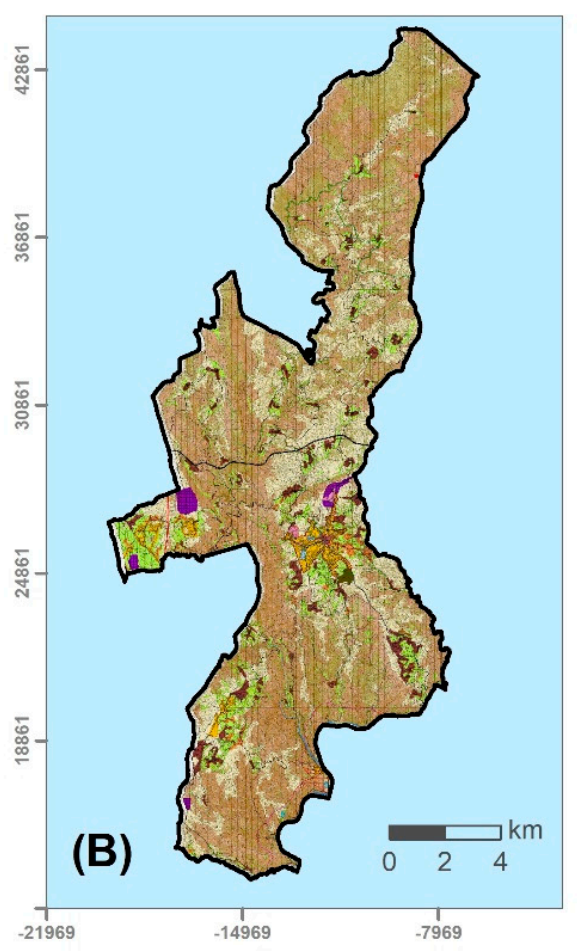

PDM

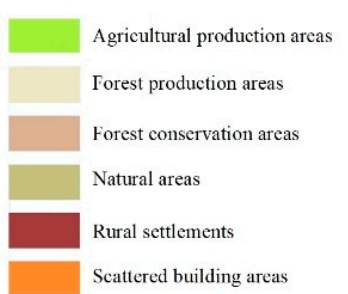

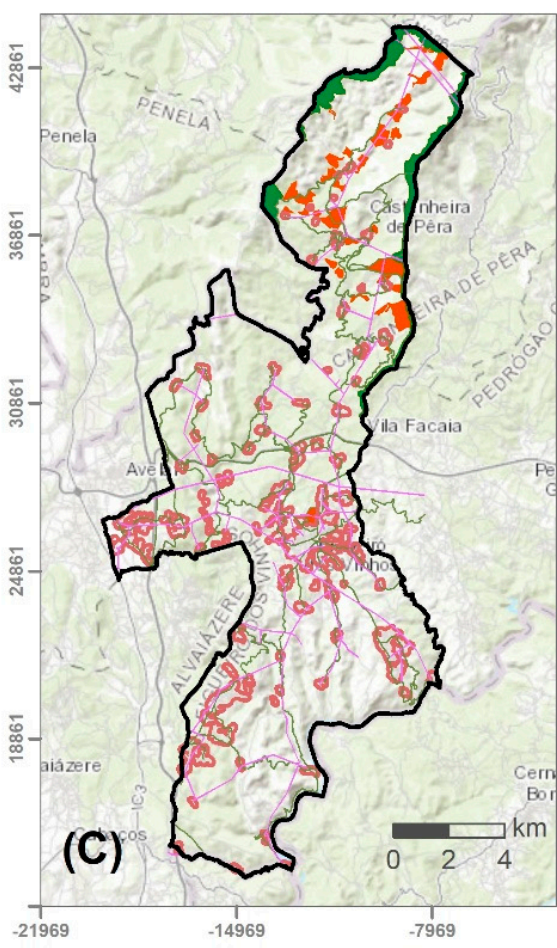

PMDFCI

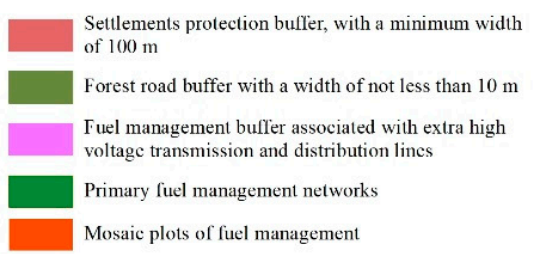

Figure 2. Current land-use plans in the Figueiró dos Vinhos Municipality. (A) Regional Forest Program (PROF), (B) Municipal Land Use Plan (PDM) and (C) Municipal Plan to Protect Forests from Fire (PMDFCI).

\section{Method}

The proposed methodology provides an integrated land-use planning model that gathers, in a spatial framework, the ecological and the cultural components responsible for improving fire resilience and ecological sustainability, designated by FIRELAN model. This methodology consists of three phases: (1) the FIRELAN conceptual model, (2) the FIRELAN GIS model-mapping criteria development within a GIS software and (3) the FIRELAN model application to a land-use proposal.

\subsection{FIRELAN Conceptual Model}

The conceptual model is based on the landscape-system concept [30,57] which defines landscape as a spatial and multifunctional system, constituted by two main subsystems: 
the network and complementary areas. The network brings together essential areas, or resources, fundamental to achieve specific landscape planning targets. The complementary areas are the interstices that result from the network and support more flexible landuses than the network. This conceptual model towards a fire resilient and sustainable landscape (FIRELAN) applies the assumptions developed in chapter 2 on landscape fire resilience (fire behavior, species combustibility, landscape discontinuities, wildland-urban interface measures), and on Ecological Network as a tool for achieving the ecological sustainability of the landscape. The FIRELAN Network (FIRELAN N) is constituted by landscape components capable of providing fire resilience and ecological sustainability, and the FIRELAN Complementary Areas (FIRELAN CA) include the remaining areas whose characteristics do not directly influence fire resilience, and despite their low ecological value, are important for a wide variety of land-uses according to their ecological suitability.

The FIRELAN is developed under the land morphology concept $[57,74,75]$, which classifies landscape components according to their position into the wet and dry systems in a river basin. This supports the understanding of the ecological functions of the different areas in a river basin, including the fire behavior, and provides a spatial tool for sustainable planning. The conceptual model spatialized based on the river basin (Figure 3A) defines a fundamental network of fire-resilient land-uses according to the ecological land suitability, providing a multifunctional landscape and also restoring the concept of familiar agriculture near the settlements.

Moreover, a schematic representation of the FIRELAN N (Figure 3B) comprises the wet system constituted by permanent and temporary streams, water bodies, valley bottoms and, in the dry system, ridges with associated hilltops and headwaters. These features comprise the principal linear network that prevents the progression of fire perpendicularly to the hillslope. This network is complemented by a subsystem transversal to the primary river basin, created to contain the longitudinal fire progression, along the hillslope. These secondary linear elements are developed along the secondary streams, the ridges, around settlements and along roads and power infrastructures. These two systems must be covered by fire-resilient land-uses, namely agriculture, pastures or broadleaved trees, to delay the fire progression towards the steepest slope, and can be complemented with fire-retardant techniques, such as the construction of swales and associated ponds, and mulching with straw or organic waste deposited on the soil. The FIRELAN CA corresponds to the FIRELAN network's interstices (Figure 3B) and foresees a more comprehensive range of land-uses, from conservation to production or building.

\subsection{FIRELAN GIS Model}

The FIRELAN GIS model consists of mapping the set of ecological and cultural components through a Geographic Information System (GIS), by overlaying data into two levels, the FIRELAN N and the FIRELAN CA, using spatial analysis tools. The FIRELAN methodology is a multi-criteria evaluation that integrates, in a single framework, the physical, the biological and the cultural landscape systems, according to several subsystems or resources (water, soil, climate, biodiversity, settlements and infrastructures) and classified by shape in linear and areas. These subsystems were selected accordingly to the conceptual model that recognizes river basin' land morphology, and species combustibility as the fundamental factors that determine fire behavior and landscape resilience. Furthermore, this methodology refers the potential land-use of each component. The FIRELAN components that coincide with the Ecological Network (EN) are marked in light green.

This methodology presented in Figure 4 was implemented in GIS using Esri ${ }^{\circledR}$ software (ArcGIS Desktop1: Release 10.7, Environmental Systems Research Institute, Redlands, CA, USA) and is developed as follows: 

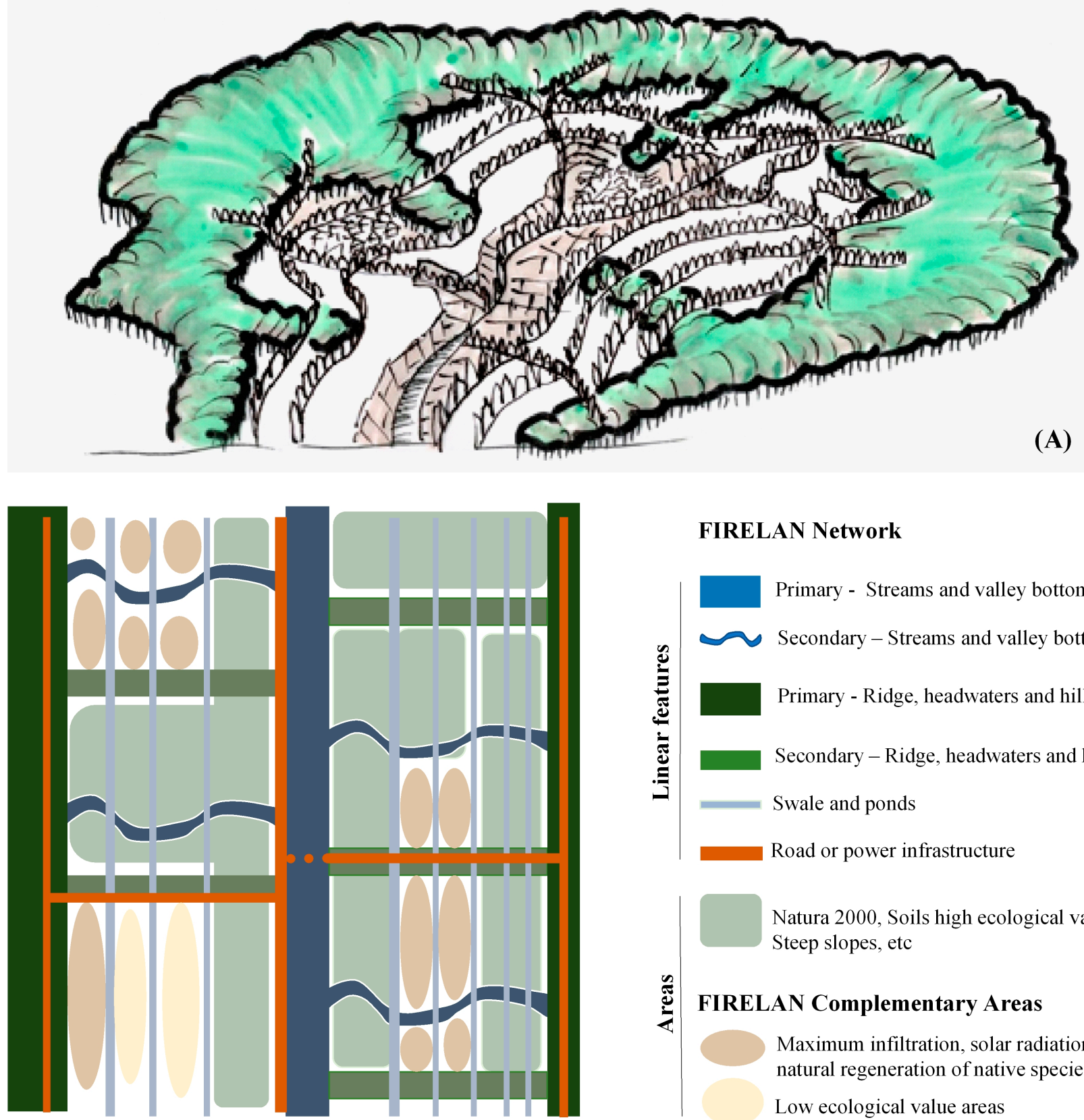

\section{FIRELAN Network}

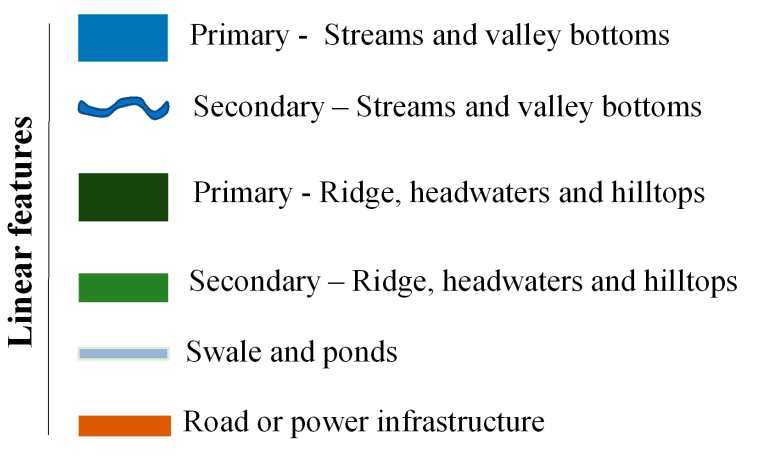

Natura 2000, Soils high ecological value, Steep slopes, etc

\section{FIRELAN Complementary Areas}

Maximum infiltration, solar radiation, natural regeneration of native species Low ecological value areas

Figure 3. FIRELAN conceptual model: (A) Conceptual river basin perspective and (B) Schematic representation. 


\section{FIRELAN - FIRE RESILIENT AND SUSTAINABLE LANDSCAPE MODEL}

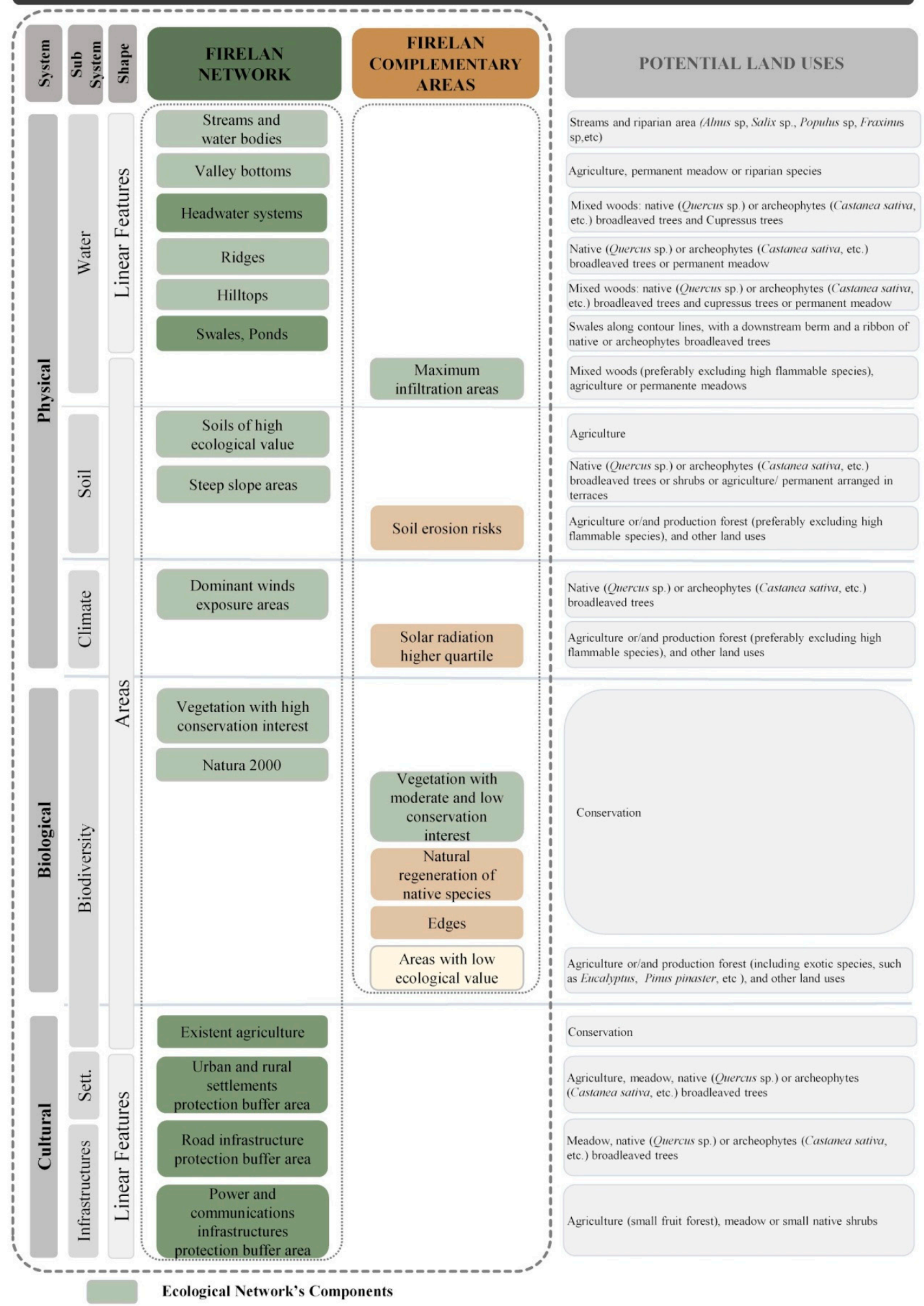

Figure 4. FIRELAN methodology.

\subsubsection{FIRELAN Network Components}

The FIRELAN N constitutes the primary protection against fire by introducing discontinuities in linear systems and areas efficient against fire progression. These discontinuities might have fire-resilient land-uses capable of lowering the fire spread velocity or even 
extinguishing it. This network should be planned based on the river basin as a unit and is constituted by:

\section{Ecological Components}

(i) Streams were ranked into four levels according to their watershed areas, streams length [76] and drainage area superior to $0.1 \mathrm{~km}^{2}$ [77] and water bodies [78].

(ii) Valley bottoms as a broad concept, which comprehends, not only floodplains, but also flat and concave areas, contiguous to streams, in which slope is less than 5\% [79].

(iii) Headwater system as the area between the ridgeline and the beginning of the streams network, whose beginning is considered with drainage area of $0.1 \mathrm{~km}^{2}$ [77].

(iv) Ridges are based on the river basins limit using drainage dimension and streams length criteria [76].

(v) Hilltops are upper areas of the drainage basin, defined as flat or convex areas with slope $<5 \%$ [75]. These areas vary in width due to erosion processes. The narrower forms correspond to the ridgeline and the wider ones to large hilltops, which are commonly referred to as plateaus.

(vi) Swales and ponds are fire-retardant techniques built along the contour lines having a berm downslope [47] with a native broadleaf trees ribbon and associated ponds. The most important swales are those that follow the key-line and the baseline. Swales do not necessarily need to be continuous, but they must not be placed on slopes greater than $25 \%$. The swales must be associated with a mulching technique, consisting of a straw layer or organic waste deposited on soil surface [48,49]. For this purpose, sacrificial trees can be used to cut the branches for deposition on the ground. These components were not mapped due to the required level of detail.

(vii) The soils of high ecological value [80] include soils with considerable soil depth and highest rates of fertility, e.g., Fluvisols, Anthrosols, Humic Cambisols (FAO and WRB classifications) and Alluvial Soils (Portuguese classification) as well as soils associated with traditional agroforestry ecosystems, with specific ecosystems, e.g., marshes. This soil evaluation was performed for mainland Portugal [81], and it is similar to the concept of soil quality [82]. These areas must be allocated to agriculture, wherever possible, providing good management of the soil and of the natural resources. Furthermore, agriculture constitutes a discontinuity of fuel material, fundamental to increase the fire resilience of the landscape.

(viii) Steep slope areas are areas with slope greater than $25 \%$ associated with high erosion levels and soil loss because of superficial or deep mass movements. The fire spreads more quickly in these areas, so fire-retardant land-uses must be ensured. The mapping was performed in GIS using a $25 \mathrm{~m}$ Digital Terrain Model [78], and the slope tool for spatial analyst.

(ix) Dominant wind exposure areas are locations where the fire increases its intensity and speed. These areas are located generally on the hillslope exposed to the dominant winds' direction (North-Northwest, in Portugal) and, in mountainous regions particularly along the ridgeline. Thus, in those areas must be ensured wind protection edges with fire-retardant species and adequate land-use. In this case study, the wind protection function is considered within the headwater systems allocated land-uses.

(x) Vegetation areas with very high and high conservation interest have high floristic richness, endangerment, naturalness, rarity and replicability. These areas were mapped based on the predictive methodology of communities and habitats and on the potential vegetation map, which considers the communities' intrinsic value [83]. Therefore, these areas must be maintained, as they constitute important genetic banks.

(xi) Natura 2000 areas include Special Areas of Conservation (SAC) created under the Habitats Directive, and the Special Protection Areas (SPAs), national parks, nature parks, nature reserves, protected landscapes, natural monuments and protected areas with private status. In Portugal, the Natura 2000 includes 60 SACs and SPAs. The data is available in the EEA platform and the ICNF geoportal. 


\section{Cultural Components}

The FIRELAN also includes the cultural system, namely:

(i) Existing agriculture areas are a crucial discontinuity of fuel material, mainly around villages, and shall be maintained and financed $[83,84]$ if necessary, particularly the family farming. This data is from the 2018 Portuguese Land Use and Land Cover Map [22].

(ii) Urban and rural settlements protection buffer area, where the land use must be restricted to low-fuel activities such as agriculture, grazing, native or archaeophytes broadleaved trees. Its width varies between $100 \mathrm{~m}$ in settlements, and up to 30 $m$ in isolated buildings (Decree-Law $n^{\circ} 10 / 2018$ ). The data used was from the OpenStreetMap $\odot$ (Open Knowledge Foundation, London, UK) and the different buffers were mapped using the buffer tool from Esri ${ }^{\circledR}$ software (ArcGIS Desktop1: Release 10.7, Environmental Systems Research Institute, Redlands, CA, USA).

(iii) Road infrastructure protection buffer area, where the land use must be restricted to low-fuel activities such as agriculture, grazing, native or archaeophytes broadleaved trees, in wide lanes: $100 \mathrm{~m}$ on motorways, $50 \mathrm{~m}$ on national roads, $10 \mathrm{~m}$ on municipal roads and $5 \mathrm{~m}$ on vicinal ways. The data used was from the OpenStreetMap $\subset$ and the different buffers were mapped using the buffer tool from ArcGIS.

(iv) Power and communication infrastructures protection buffer area defined with different widths ranging from 15 to $45 \mathrm{~m}$ following the Portuguese law (ImplementingDecree $n^{\circ} 1 / 92$ de 18/2/1992). In these areas the land use must be restricted to low-fuel activities such as agriculture, grazing (meadows) or small native shrubs. The different buffers were mapped using the buffer tool from ArcGIS.

\subsubsection{FIRELAN Complementary Areas Components}

The FIRELAN Complementary Areas (FIRELAN CA) are the interstitial areas of the FIRELAN Network and only indirectly contribute to fire resilience of the landscape. However, their ecological characterization is important for the land-uses proposal, according to their ecological suitability.

(i) Maximum infiltration areas have high permeability resulting from the evaluation of geology, soil, slope and land cover [85]. They guarantee freshwater supplies and water availability (groundwater recharge), contributing to decreasing the runoff and erosive processes. These areas increase fire resilience and increase soil and water conservation if they have suitable land use covers, namely biodiverse pastures, native bushes or native or archaeophytes broadleaved trees.

(ii) Areas with high soil erosion risks depend on soil characteristics, the length of the hillslopes, and precipitation amount per time unit. In addition to the steep slope areas (slope above $25 \%$ ) these areas also include hillslope under $25 \%$. These soil erosion risks should be prevented with the appropriate land use cover and, if needed, with techniques to promote water infiltration and erosion reduction. The soil erosion risk map was based on the potential soil erosion calculated through erodibility (K), erosivity (R) and the topographic factor (LS) of the Revised Universal Soil Loss Equation [81]. These areas also contribute to fire resilience if they have suitable land use cover.

(iii) Areas with the higher solar radiation quartile present a higher risk of fire occurrence [34]. These areas have higher air and soil temperatures. The annual solar radiation is characterized by latitude and elevation, steepness slope, aspect and effects of shadows cast by surrounding topography [86]. It was calculated using solar radiation tool from Esri ${ }^{\circledR}$ software (ArcGIS Desktop1: Release 10.7, Environmental Systems Research Institute, Redlands, CA, USA), with the mean value of 0.56 for atmospheric transmissivity for the study area. Fire-retardant species should compose the land use cover.

(iv) Vegetation areas with low and very low conservation value correspond to the existent vegetation whose conservation value is not high enough to receive an endangered sta- 
tus, such as annual grasslands and meadows with low biodiversity. The regenerative capacity presented in such areas is important to the wildlife community. Mesquita [83] modeled the data used.

(v) Natural regeneration areas of native species need to be conserved because they have higher restoration success. These areas were not mapped in the case study because it would require fieldwork on a scale of detail than that of this study.

(vi) Edges with native vegetation to ensure biodiversity. The creation or conservation of edges, in agriculture or forest production stands, can protect from dominant winds, decrease evaporation and avoid fire progression. In terraces, edges with stonewalls will allow agriculture or pastures installation, which will introduce fuel voids in those areas. These elements were not mapped in the case study because of the detailed scale needed.

(vii) Low ecological value areas support a wider range of uses. In these areas, it is possible, in the light of the concepts underlying this paper, including fast growing species.

\subsection{FIRELAN Potential Land-Uses}

The last phase of the FIRELAN method is to propose potential land-uses according to the ecological land suitability of each component (Figure 4) based on the studies developed in Magalhães [69]. Fire resilient land-use should be assigned to the FIRELAN Network components in order to provide landscape resilience. Relatively to the FIRELAN CA more flexible uses may assume a complementarity for fire resilience.

The fire resilient land-uses are composed of native or archaeophytes broadleaved trees, agricultural areas, permanent meadows, water elements or void spaces, such as roads or even bare areas. The choice of native species referred to in the theoretical framework must be selected according to potential natural vegetation [87], depending on the function that a specie or mixture of species can ensure in the ecosystem. For example, Molkanov [88] states that, due to the nature of the produced dead layer, the most suitable cover for water retention and infiltration, is a mixture of broadleaved trees and Cupressaceae (mixed woods). As for agricultural land use, the current agricultural areas must be maintained and encouraged in areas with higher fertility. In the areas where it is advisable by law, to keep the land clear of vegetation, such as power-infrastructure buffer areas, the land-use should at least be a meadow to prevent soil erosion. In complementary areas, the uses are more flexible, but also have to be defined depending on the land suitability. Pinus pinaster and Eucalyptus sp. are assigned to the complementary areas with low ecological value.

\section{Results}

The FIRELAN model was applied to an intermunicipal case study, which comprises three municipalities from the center region of Portugal: Pedrógão Grande, Castanheira de Pêra and Figueiró dos Vinhos (Figure 1).

\subsection{FIRELAN MaP}

The FIRELAN map comprises the FIRELAN network and the complementary areas. The FIRELAN network (Figure 5) comprises $79 \%$ of the case study total area, mainly dominated by rugged mountainous relief. The FIRELAN network components with the highest representativeness in the case study area are the steep slope areas $(41.3 \%)$, the headwater systems $(28.4 \%)$ and the Natura 2000 Network $(14.8 \%)$. The linear features from FIRELAN network are $46 \%$ of the study area (Table 1), in which $32 \%$ are ridgesrelated features such as headwaters, hilltops and ridges, and about $9 \%$ are water-related features, such as streams, valley bottoms and water bodies. The linear features associated with the cultural system (settlements, roads and power infrastructures protection buffer) consist of $13 \%$ of the case study area (Table S1). The existing agriculture, which is located mainly around rural settlements, occupies only $8.5 \%$ of the study area and does not entirely surround the settlements (Table S1), so the protection buffer area proposal must envisage its fulfillment. 

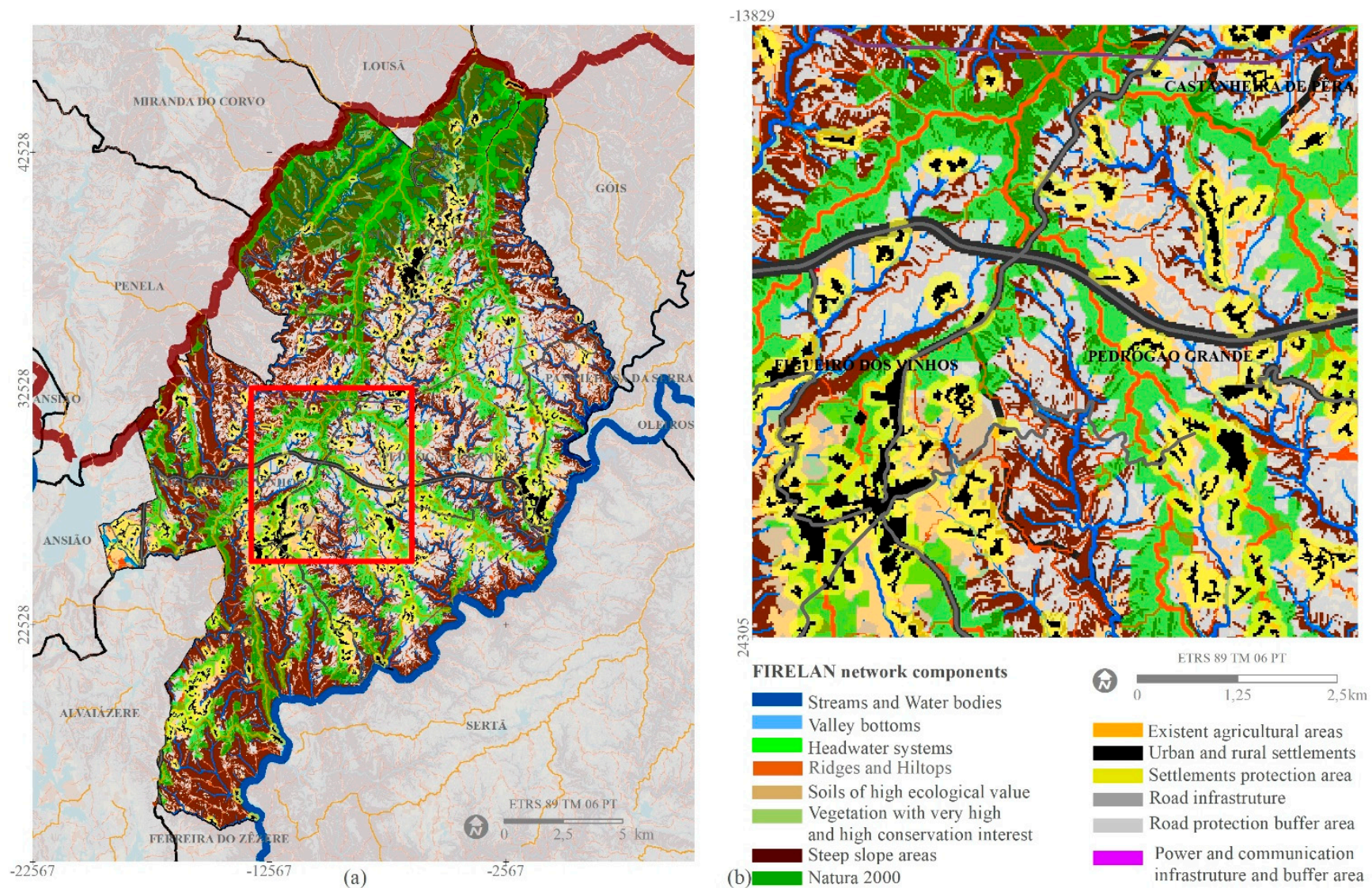

Figure 5. (a) FIRELAN Network components; (b) detail.

Table 1. FIRELAN model in the case study area, area (ha) and percentage of total study area.

\begin{tabular}{|c|c|c|c|c|c|}
\hline \multicolumn{2}{|c|}{ Fire Resilient and Sustainable Landscape Model (FIRELAN) } & \multicolumn{2}{|c|}{ Area (ha) } & \multicolumn{2}{|c|}{$\%$ Total Study Area } \\
\hline \multirow{2}{*}{ FIRELAN Network } & Linear Features & 17,094 & \multirow{2}{*}{29,221} & 46.4 & \multirow{2}{*}{79.4} \\
\hline & Areas * & 12,128 & & 32.9 & \\
\hline \multirow{2}{*}{ FIRELAN Complementary Areas ** } & with Ecological Value & 4270 & \multirow{2}{*}{6415} & 11.6 & \multirow{2}{*}{17.4} \\
\hline & with low Ecological Value & 2146 & & 5.8 & \\
\hline \multirow{2}{*}{ Cultural system } & Urban and rural settlements & 1121 & \multirow{2}{*}{1187} & 3 & \multirow{2}{*}{3.2} \\
\hline & Road infrastructure & 66 & & 0.2 & \\
\hline
\end{tabular}

* Excluding those overlapping the Linear features from FIRELAN Network. ${ }^{* *}$ Excluding those overlapping the FIRELAN Network.

The FIRELAN CA are the remaining areas of the FIRELAN $\mathrm{N}$ and occupy $17 \%$ of the case study area, of which one third has low ecological value. In the total area of the components used to characterize the FIRELAN CA, a part is included in the FIRELAN N. For instance, $69 \%$ of the study area has higher potential soil erosion. However only $8.9 \%$ is contemplated in FIRELAN CA. The coexistence of both network and complementary areas components revealed on the FIRELAN map (Figure 6) occurs in this particular case study. 


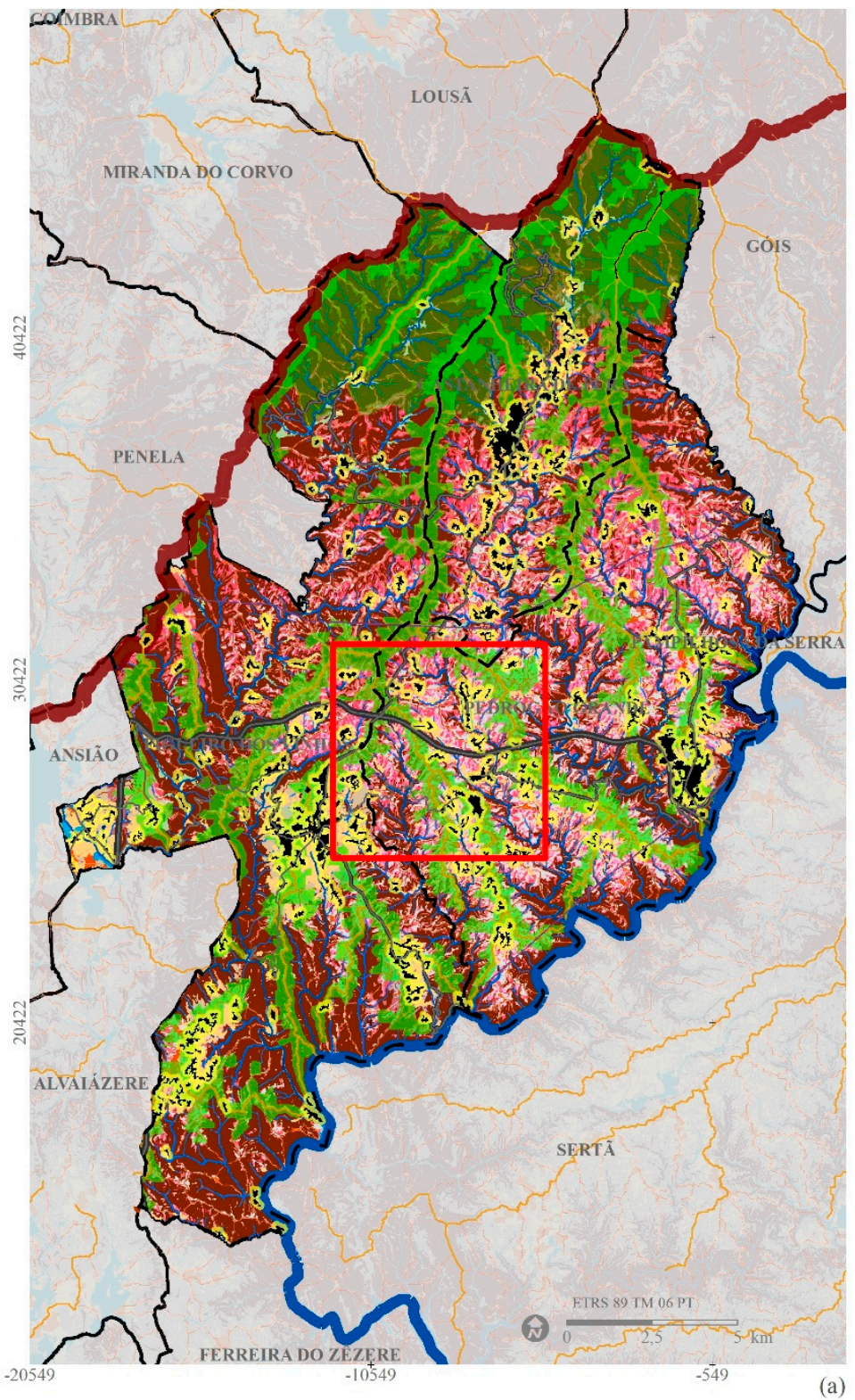

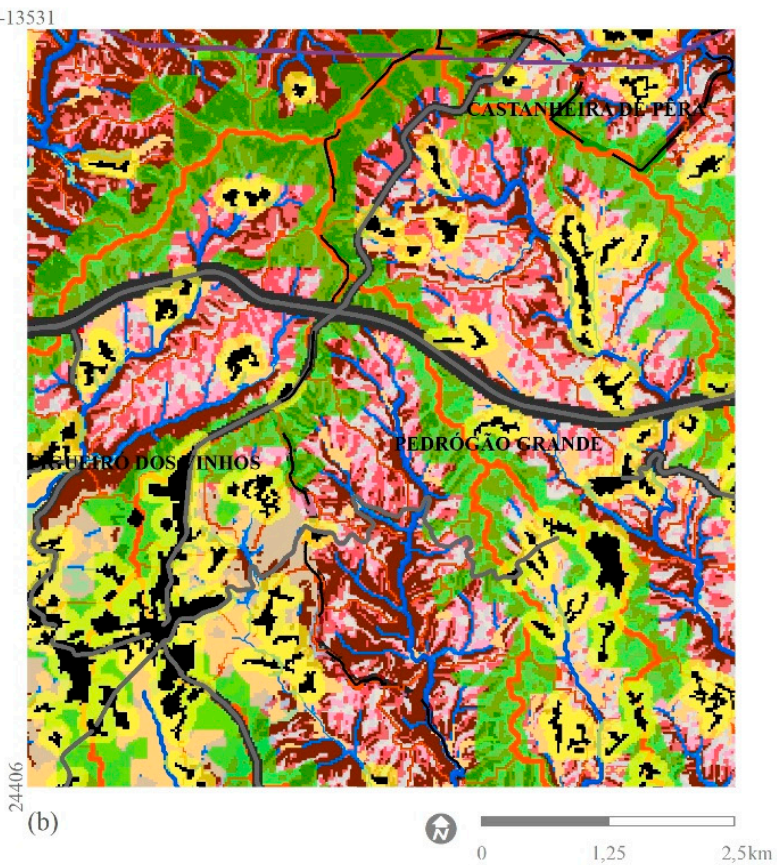

FIRELAN Network components
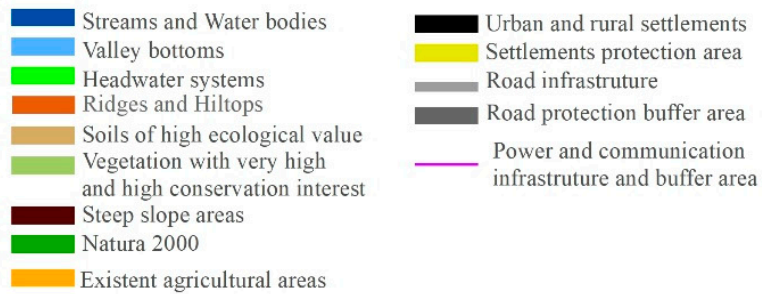

FIRELAN Complementary areas components

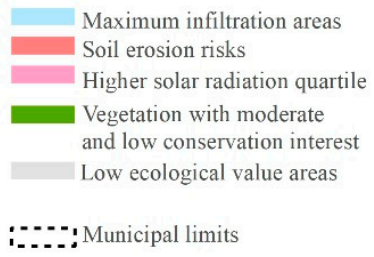

(a)

Figure 6. (a) FIRELAN Network and Complementary Areas components; (b) detail.

The FIRELAN CA components with ecological value are the higher solar radiation quartile (7\% of the total case study area), the higher potential soil erosion areas $(8.9 \%)$, the maximum infiltration areas $(0.3 \%)$ and the vegetation with moderate and low conservation interest $(<0.01 \%)$. The latest is the vegetation from the early stages of ecological succession that should be managed and conserved to evolve to the climax forest. In the areas with solar radiation from the higher quartile, which may contribute to the spread of fire, the land-uses should be preferably constituted by less combustible species or open spaces (agriculture/meadows). The soil erosion risks and maximum infiltration areas should have a land cover and management practices that protect the soil from erosion, aquifer contamination and improve water infiltration.

The FIRELAN CA with low ecological value allows flexible land-use planning, namely introducing of exotic species plantations with shorter exploration cycles. It represents $5.8 \%$ of the study area. However, examining each municipality individually, these areas may reach $10 \%$ of the municipality area (e.g., Pedrógão Grande municipality). 
About $79 \%$ of the FIRELAN N is coincident with the Ecological Network (EN) already delimited by the team $[58,64]$, which validates the assumption that the FIRELAN model, besides fire resilience, also considers the ecological sustainability of the landscape, ensured by the EN.

Figure 7 shows that all municipalities have a very representative FIRELAN N, considering the total area. Pedrogão Grande is the municipality with lesser areas from FIRELAN network (69\%) and higher Complementary Areas, comprising $28 \%$ of the municipality area. From the three municipalities, Figueiro dos Vinhos, with the higher burnt area, is the one that requires higher soil and water conservation land-uses, as steep slopes, high quality soils and Natura 2000 areas are very representative. In the latter, the Complementary Areas are smaller and only $3 \%$ have low ecological value, where the current land-uses of $P p$ and $E g$ are adequate.

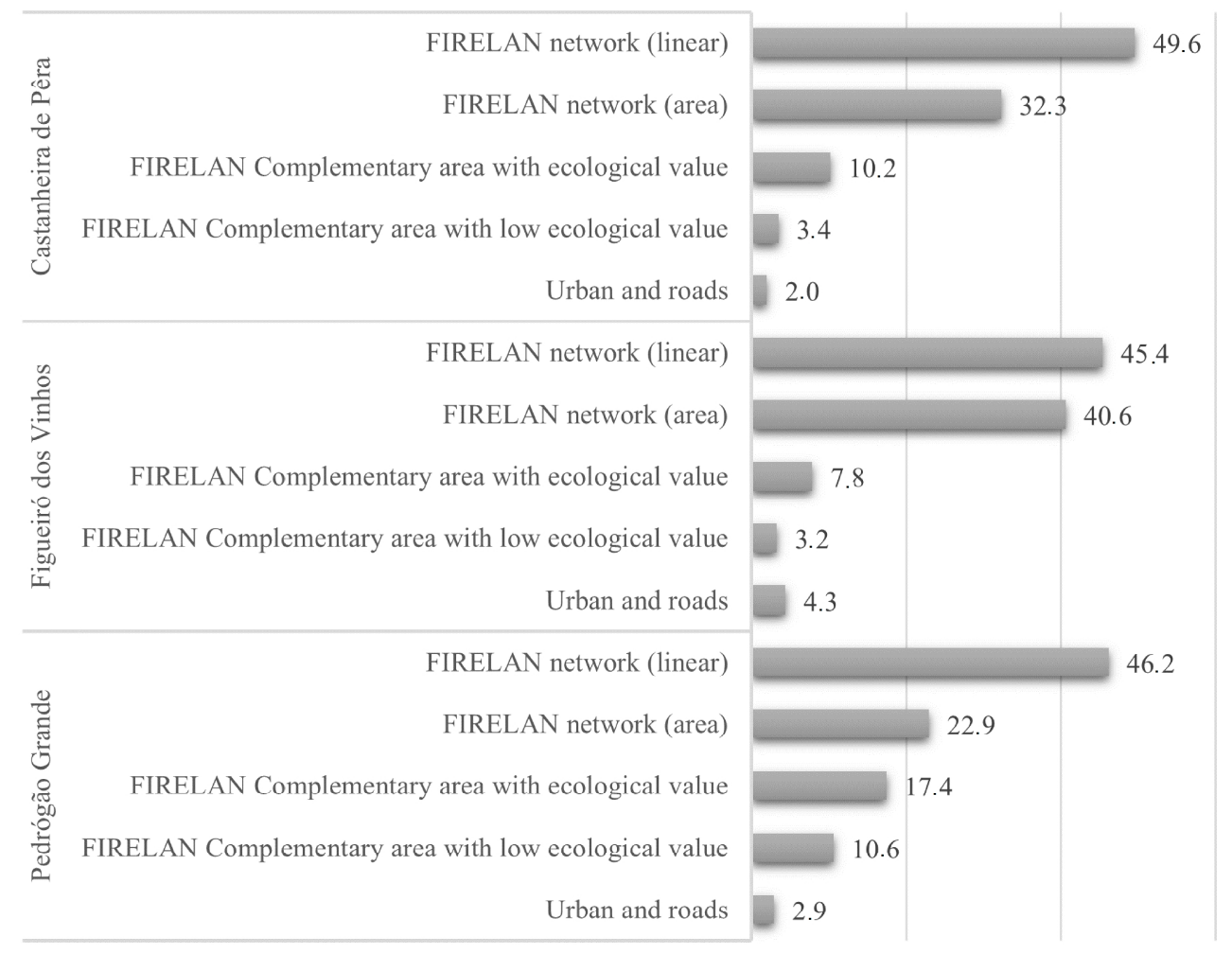

Figure 7. FIRELAN mapping results in the different municipalities.

\subsection{FIRELAN Land-Use Plan and Landscape Transformation Actions}

Based on the FIRELAN model's components, a land-use plan with alternative uses was defined according to the ideal landscape to provide a fire resilient and sustainable landscape. The methodology applied in the case study is presented in Figure 8A. Since each FIRELAN components provides for alternative uses, the results regarding the most critical classes of land-use show that: (i) the native species, with an existent area of 312 ha ( $0.8 \%$ of total area), should increase between $48.4 \%$ and $60.5 \%$ of the case study; (ii) the riparian vegetation should occupy $5.7 \%$ of the case study area; (iii) the existent agriculture $(8.5 \%)$ can be expanded between 660 ha $(1.8 \%)$ considering only the high ecological value soils, and 8938 ha (24.3\%) considering the high ecological value soils and the completion of the buffer around settlements and other marginal areas; and (iv) the existing Pp and Eg covering $73 \%$ of the case study area should decrease drastically to $5.8 \%$ that corresponds to the FIRELAN CA with the low ecological value. About $70 \%$ of this agricultural expansion potential is located in the buffer around the settlements. 

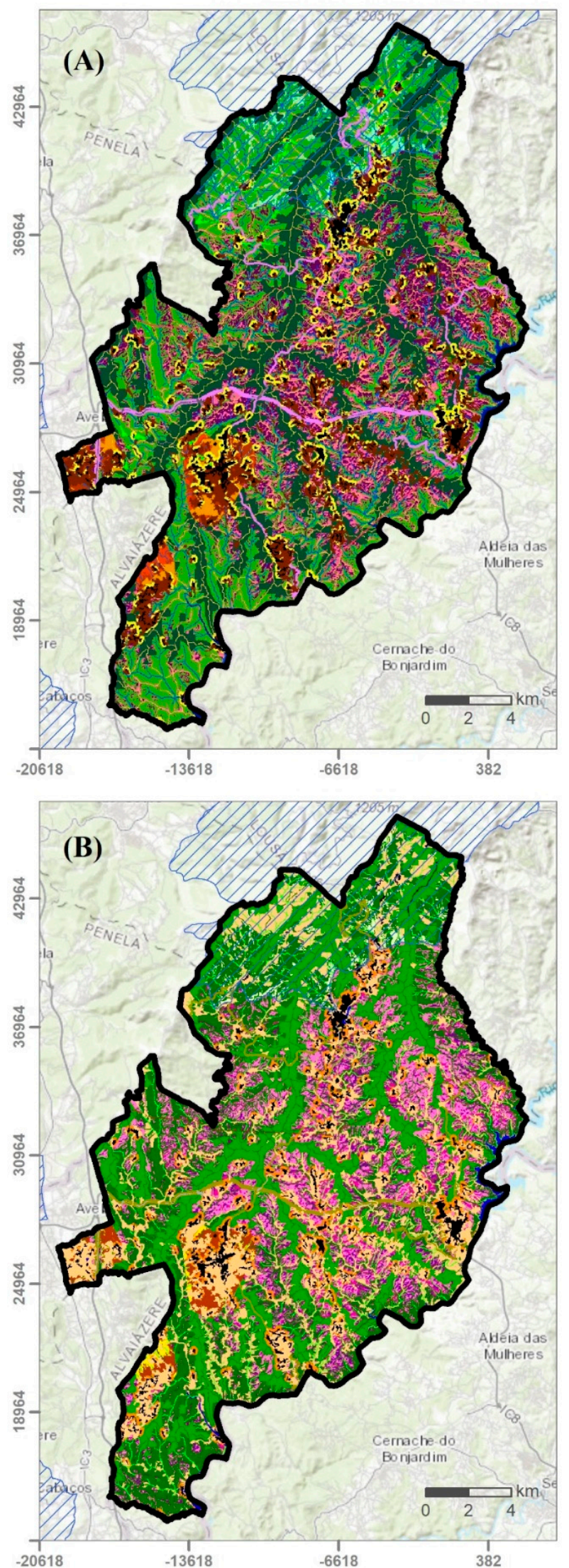

FIRELAN - Land Uses Proposal

Potential land uses

Mixed woods (native/archeophytes and cupressus trees) Headwater systems

Native/archeophytes broadleaved trees or shrubs Steep slope areas

Native/archeophytes broadleaved trees or permanent meadows Ridge line

Mixed woods (native/archeophytes and cupressus trees) or permanent meadow Hilltops

Riparian vegetation Streams and narrow valley bottoms

Natural regeneration Natura 2000

Agriculture High ecological value soils

Agriculture (edges of mixed woods - native/archeophytes and coniferous trees) Headwater systems

Agriculture or permanent meadow arranged in terraces Steep slope areas with high ecological value soils

Agriculture or/and production forest (including exotic trees) and other land uses FIRELAN complementary areas without ecological value

Agriculture or/and production forest (preferably excluding high flammable species), and other land uses FIRELAN complementary areas with ecological value

$\square$ Agriculture, meadow, native/archeophytes broadleaved Settlement protection buffer

Meadow or native/archeophytes broadleaved trees Roads protection buffer

Agriculture (small fruit forest), meadow or small native shrubs Power infrastructures protection buffer

\section{Existent land uses}

\section{$\square$ Existent vegetation with conservation interest}

Existent agriculture

\section{FIRELAN - Transformation Actions}

Areas to be converted into :

native/archeophytes broadleaved

mixed woods

\section{riparian vegetation}

natural regeneration in natura 2000

agriculture

$\square$ agriculture or meadows (with terraces) meadow in roads buffer

agriculture (small fruit forest), meadow or small native shrubs under power infrastructures

agricultute, meadow, native species/archeophytes broadleaved trees in settlement buffer

pinus or eucaliptus

production forest (preferably excluding high flammable species), agriculture or other land uses

\section{Areas to be mantained/conserved:}

with pinus and eucaliptus with other land uses

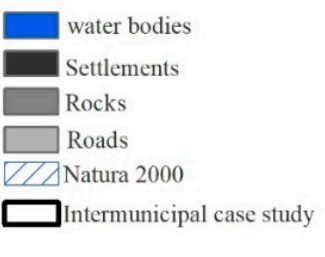

Figure 8. (A) FIRELAN land-use plan and (B) FIRELAN transformation actions. 
The landscape transformation actions map is based on the comparison between the current land-use [22] and the FIRELAN land-use plan. The results (Table 2) show that about $24 \%$ of the case study has a land use adequate to its ecological circumstances and should be maintained. However, the findings indicate that $72 \%$ would benefit from transformation actions. The Land Use and Land Cover map [18] shows that before the 2017 fire, the case study area was densely occupied by Pinus pinaster (maritime pine) and Eucalyptus globulus (73\%) (Figure 1C). Consequently, the dominant transformation action comprises the conversion of maritime pine and eucalyptus into native, archaeophyte broadleaved forest, mixed woods or other fire resilient land-uses. This conversion also happens in Natura 2000 areas, suggesting the need to define an accurate transformation plan in nature conservation classified areas.

Table 2. Area and percentage of the proposed land use classes in the case study.

\begin{tabular}{|c|c|c|c|}
\hline Proposed Land-Use Plan Classes & Total Area (ha) & $\begin{array}{c}\% \text { of Total } \\
\text { Case Study Area }\end{array}$ & $\begin{array}{l}\text { FIRELAN Components } \\
\text { (Main) }\end{array}$ \\
\hline $\begin{array}{c}\text { Agriculture (edges of mixed } \\
\text { woods—native/archaeophytes and cupressus trees) }\end{array}$ & 246 & 0.67 & $\begin{array}{l}\text { Headwater systems and High } \\
\text { ecological value soils }\end{array}$ \\
\hline Native/archaeophytes broadleaved trees or shrubs & 10,352 & 28.11 & Steep slope areas \\
\hline $\begin{array}{c}\text { Native/archaeophytes broadleaved trees or } \\
\text { permanent meadow }\end{array}$ & 1762 & 4.79 & Ridge line \\
\hline $\begin{array}{c}\text { Mixed woods (native/archaeophytes and cupressus } \\
\text { trees) or permanent meadow }\end{array}$ & 113 & 0.30 & Hilltops \\
\hline Riparian vegetation & 1876 & 5.10 & $\begin{array}{l}\text { Streams and narrow valley } \\
\text { bottoms }\end{array}$ \\
\hline Natural regeneration in Natura 2000 & 461 & 1.25 & - \\
\hline Agriculture & 249 & 0.68 & High ecological value soils \\
\hline $\begin{array}{l}\text { Mixed woods (native/archaeophytes and } \\
\text { cupressus trees) }\end{array}$ & 7463 & 20.26 & Headwater systems \\
\hline $\begin{array}{l}\text { Agriculture or permanent meadow arranged } \\
\text { in terraces }\end{array}$ & 165 & 0.45 & $\begin{array}{l}\text { Steep slope areas with } \\
\text { ecological value soils }\end{array}$ \\
\hline $\begin{array}{c}\text { Agriculture or/and production forest (including exotic } \\
\text { trees), and other land-uses }\end{array}$ & 2146 & 5.8 & $\begin{array}{l}\text { FIRELAN CA with low } \\
\text { ecological value }\end{array}$ \\
\hline $\begin{array}{l}\text { Agriculture or/and production forest (excluding high } \\
\text { flammable species) }\end{array}$ & 4270 & 11.6 & $\begin{array}{l}\text { FIRELAN CA with } \\
\text { ecological value }\end{array}$ \\
\hline $\begin{array}{c}\text { Agriculture, meadow, native species/archaeophytes } \\
\text { broadleaved trees }\end{array}$ & 1733 & 4.71 & Settlement protection buffer \\
\hline Meadow, native/archaeophytes broadleaved trees & 861 & 2.34 & Roads protection buffer \\
\hline $\begin{array}{c}\text { Agriculture (small fruit forest), meadow or small } \\
\text { native shrubs }\end{array}$ & 130 & 0.35 & $\begin{array}{l}\text { Power infrastructures } \\
\text { protection buffer }\end{array}$ \\
\hline Existent agriculture & 3123 & 8.48 & - \\
\hline Existent vegetation with conservation interest & 310 & 0.84 & - \\
\hline Water bodies & 378 & 1.03 & Water bodies \\
\hline Roads & 66 & 0.18 & - \\
\hline Settlements & 1121 & 3.05 & - \\
\hline
\end{tabular}

According to the FIRELAN model, 5.8\% of the area (2146 ha) is suitable for exotic trees $(P p$ and $E g)$. However, in these areas, the analysis of transformation actions (Table 3) revealed that $5.5 \%$ already have eucalyptus and maritime pine. Therefore, this land-use can be expanded only in the remaining area, which is $0.3 \%$ (162 ha) of the case study area. Of the total area to be maintained and conserved, $46.9 \%$ is currently agriculture, 
$29.5 \%$ is native forest, $23 \%$ is shrubs. Analyzing the transformation actions (Figure 9 ), the preceded land-uses dominant for each transformation actions are eucalyptus and maritime pine forest. Only shrubs are dominant in the area to be converted to mixed woods in Natura 2000.

Table 3. Transformation and conservation actions, area and percentage.

\begin{tabular}{|c|c|c|c|c|c|}
\hline & Transformation Actions & \multicolumn{2}{|c|}{ Area (ha) } & \multicolumn{2}{|c|}{$\%$} \\
\hline \multirow{13}{*}{$\begin{array}{l}\text { Areas to be } \\
\text { converted into }\end{array}$} & Native/archaeophytes broadleaved forest in Natura 2000 & 1954 & \multirow{13}{*}{26,657} & 5.3 & \multirow{13}{*}{72.3} \\
\hline & Native/archaeophytes broadleaved forest & 8496 & & 23.1 & \\
\hline & Mixed woods in Natura 2000 & 1567 & & 4.3 & \\
\hline & Mixed woods & 5745 & & 15.6 & \\
\hline & Riparian vegetation & 1401 & & 3.8 & \\
\hline & Natural regeneration should be developed in Natura 2000 & 346 & & 0.9 & \\
\hline & Agriculture & 446 & & 1.2 & \\
\hline & Agriculture or meadows (with terraces) & 143 & & 0.4 & \\
\hline & Meadow in roads buffer areas & 804 & & 2.2 & \\
\hline & $\begin{array}{l}\text { Agriculture (small fruit forest), meadow or small native } \\
\text { shrubs under power infrastructures }\end{array}$ & 101 & & 0.3 & \\
\hline & $\begin{array}{l}\text { Agriculture, meadow, native species/archaeophytes } \\
\text { broadleaved trees in WUI }\end{array}$ & 1388 & & 3.8 & \\
\hline & Maritime pine or eucalyptus & 162 & & 0.3 & \\
\hline & $\begin{array}{l}\text { Production forest (preferably excluding high flammable } \\
\text { species), agriculture or other land-uses }\end{array}$ & 4104 & & 11.1 & \\
\hline \multirow{2}{*}{$\begin{array}{l}\text { Areas to be } \\
\text { conserved }\end{array}$} & Maritime pine and eucalyptus to be maintained & 2027 & \multirow{2}{*}{8587} & 5.5 & \\
\hline & Areas to be maintained and conserved & 6560 & & 17.9 & \\
\hline & Rocks & & 12 & & 0.03 \\
\hline & Settlements & & & 1121 & 3.0 \\
\hline & Roads & & & 66 & 0.2 \\
\hline & Water bodies & & & 380 & 1.0 \\
\hline
\end{tabular}

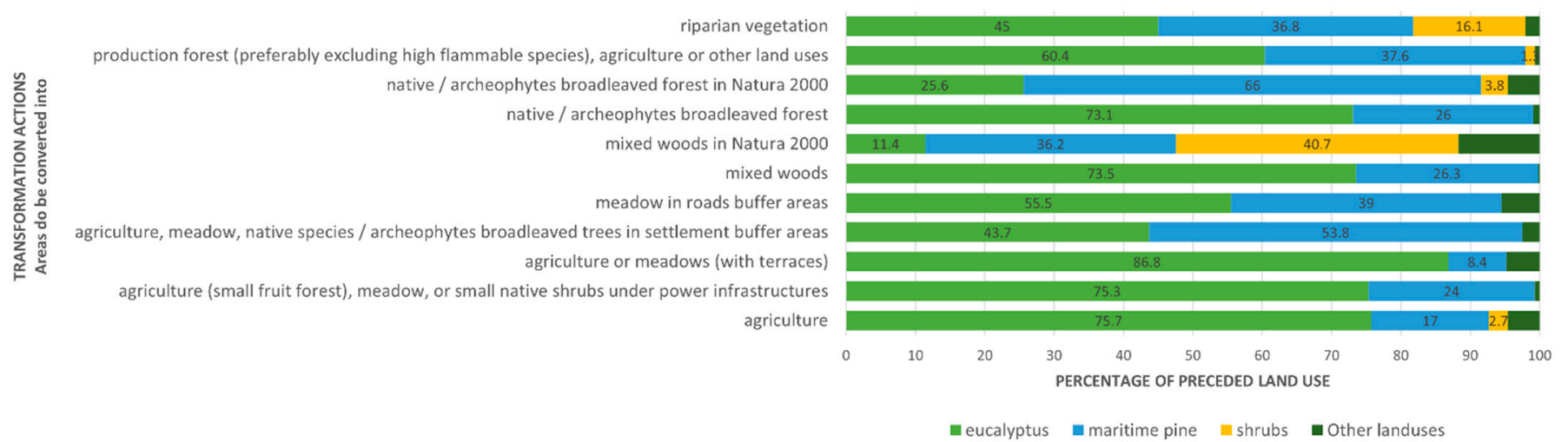

Figure 9. Percentage of preceded land use for each transformation action.

This map allows a more straightforward identification of the transformation actions, providing the basis for assessing cost evaluation. Simultaneously, mapping these transformation actions enables its translation into management actions, providing planning tools for technical assistance projects and investment development. With these instruments, 
the municipalities can make more informed decisions and apply for financing for the implementation.

\subsection{Comparison between Plans}

The FIRELAN network (N) from Figueiró dos Vinhos was spatially compared with the Fire protection Municipal plan (PMDFCI). The comparison (Figure 10) confirmed that only $17 \%$ of the case study area is coincident between that plan and FIRELAN N, leaving $72 \%$ of the FIRELAN N unprotected by the PMDFCI (Table 4 ). About $0.7 \%$ of the case study corresponds to areas without FIRELAN network and with PMDFCI, which are residual areas of the mosaic plot of fuel management mapped by the latter whose justification is not clarified. However, the PMDFCI compared only with the FIRELAN Network's linear components, the unprotected areas fall to $36 \%$ (Table 5) because the cultural system's linear components coincide entirely with the PMDFCI. If there is a need to establish implementation priorities, only the linear elements, including the headwater systems, the hilltops and the streams, can be considered in a first phase.

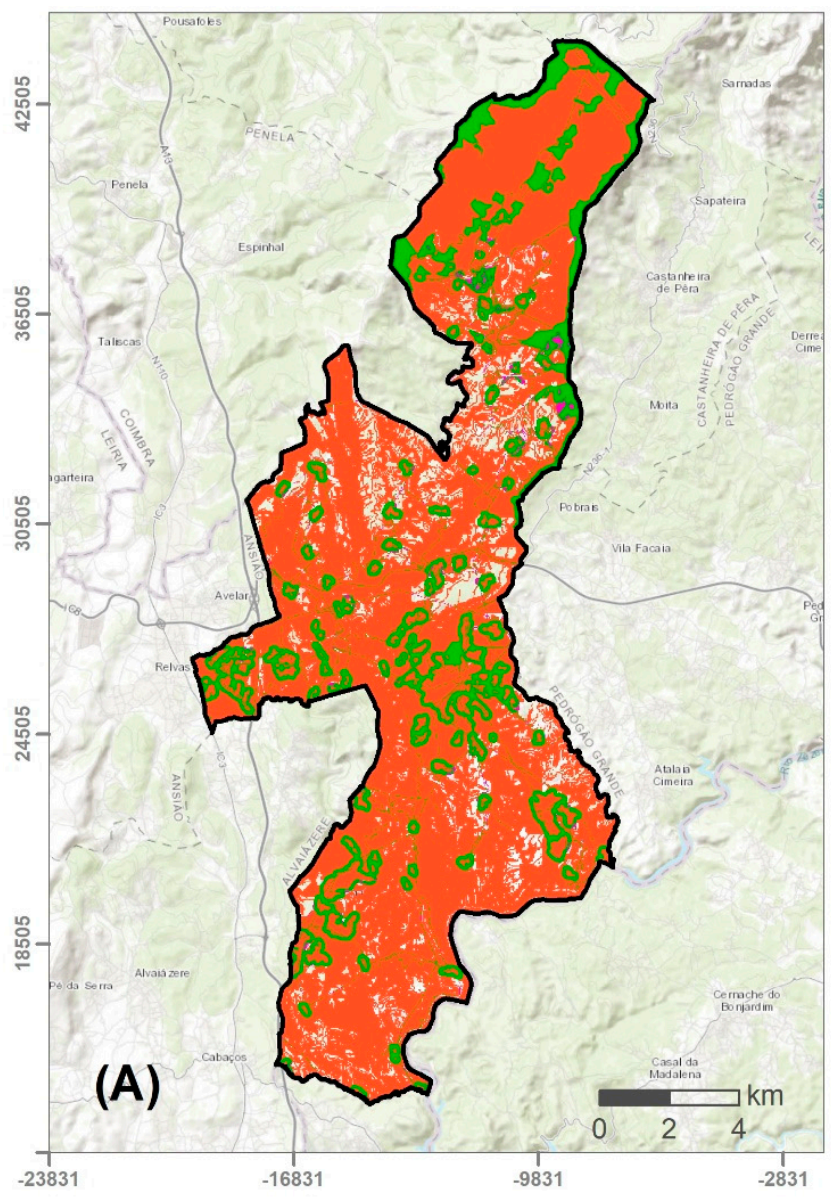

FIRELAN Network vs. PMDFCI

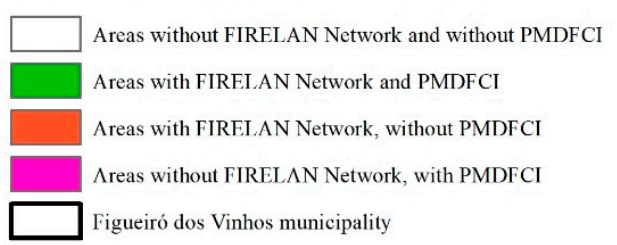

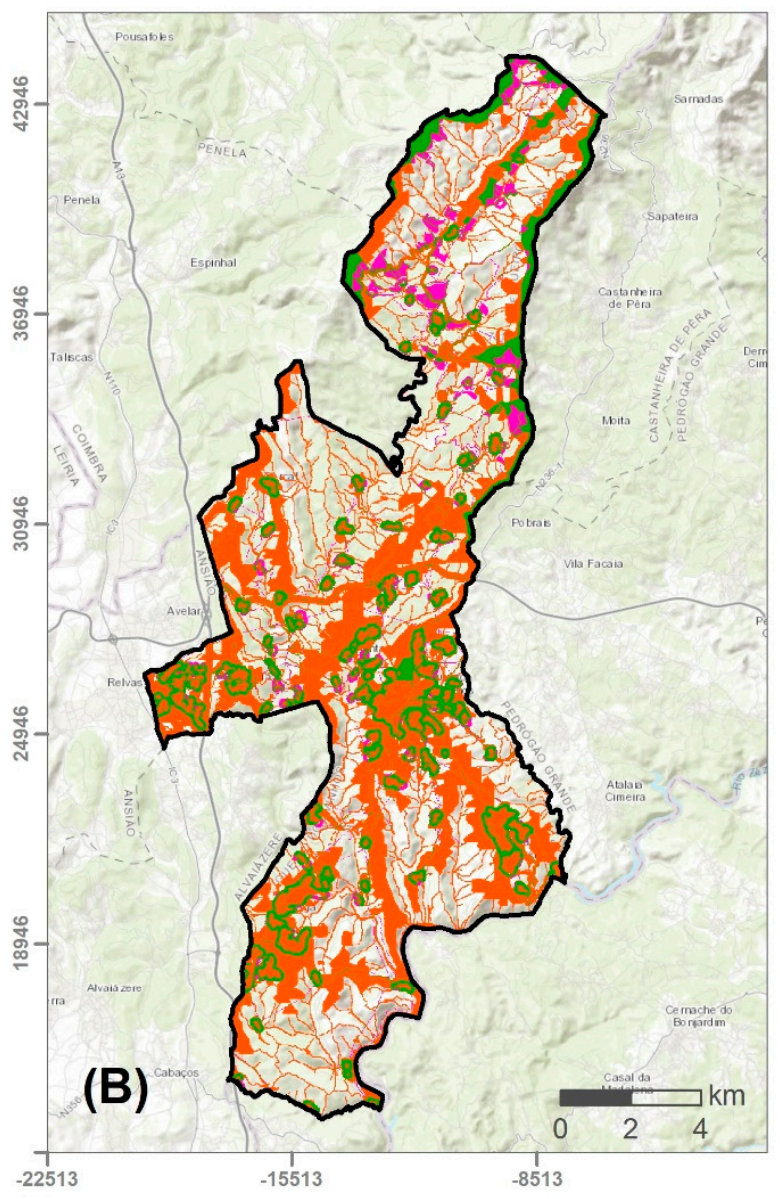

FIRELAN Network (Linear) vs. PMDFCI

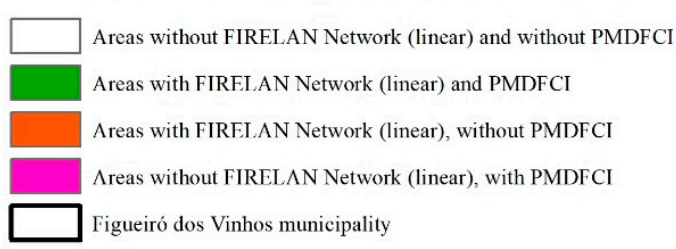

Figure 10. Comparison between FIRELAN network and PMDFCI in Figueiró dos Vinhos municipality: (A) FIRELAN N; (B) Linear features of FIRELAN N. 
Table 4. Comparison between FIRELAN network and PMDFCI from Figueiró dos Vinhos.

\begin{tabular}{ccc}
\hline FIRELAN vs. PMDFCI & Area (ha) & \multicolumn{2}{c}{ \% of the Case Study Area } \\
\hline Areas with FIRELAN N without PMDFCI & 12,588 & 72.7 \\
\hline Areas with FIRELAN N and PMDFCI & 2934 & 16.9 \\
\hline Areas without FIRELAN N with PMDFCI & 116 & 0.7 \\
\hline Areas without FIRELAN N and without PMDFCI & 1684 & 9.7 \\
\hline
\end{tabular}

Table 5. Comparison between linear components of FIRELAN network and PMDFCI from Figueiró dos Vinhos.

\begin{tabular}{ccc}
\hline FIRELAN Network (Linear) vs. PMDFCI & Area (ha) & \% of the Case Study Area \\
\hline Areas with FIRELAN N (linear), without PMDFCI & 6311 & 36.4 \\
\hline Areas with FIRELAN N (linear) and PMDFCI & 2402 & 13.9 \\
\hline Areas without FIRELAN N (linear), with PMDFCI & 647 & 3.7 \\
\hline Areas without FIRELAN N (linear) and without PMDFCI & 7961 & 46.0 \\
\hline
\end{tabular}

On the other side, Figueiró dos Vinhos municipal's land-use plan indicates a vast area of "forest conservation" class where native species must be planted, and fast-growing species afforestation is prohibited, showing a clear intention of the municipality in replacing the current eucalyptus forest. This transformation intention is consistent with the land-use proposal from the FIRELAN model (Figure 7) but inconsistent with the PROF-CL, which indicates that the Eucalyptus globulus (Eg) area should not exceed 7500 ha, representing 43\% of Figueiró dos Vinhos municipality. The FIRELAN Land use plan establishes a limit of $3.2 \%$ for Eucalyptus globulus (Eg), in the low ecological value areas, far less than the limits set in the PROF-CL.

\section{Discussion}

This paper explores the role of landscape planning as an important tool for rural fires prevention. According to FAO [89], fire prevention includes any actions that may prevent the outbreak of fire or reduce fire spread and severity. San-Miguel-Ayanz [5] have concluded that firefighting alone is not efficient to extinguish megafires. Therefore, the development of fire prevention models is essential to solving the problem. This discussion is currently very much alive in the public arena.

In the mainstream opinion, the intensive land-use of maritime pine and eucalyptus is generally considered the best economic option, associated with fuel management and short production cycles. This opinion implies a highly flammable homogeneous landscape, which will increase fire severity and require higher economic costs in firefighting (for every taxpayer), whereas this type of forest production benefits mainly the intermediaries of the wood business and the pulp and biomass industries. Moreover, studies on tree species' flammability proved that native broadleaved species burn less than Pinus pinaster and Eucalyptus globulus. Furthermore, this land-use is causing landscape degradation, and abandonment, loss of biodiversity and increasing the number, and intensity of natural catastrophes, such as rural fires, landslides, floods and soil erosion.

In this study, the authors developed the FIRELAN conceptual and ecologically based model that recognizes the river basin' land morphology, the microclimate and the dominant land-use as the fundamental factors that determine fire behavior. The model establishes the need to create discontinuities in the landscape with less combustible land-uses and apply permaculture techniques, such as swales and ponds, towards a more fire resilient landscape. In addition, this model has the advantage of ensuring the ecological sustainability of the landscape using ecological land suitability for the proposed land-uses. The FIRELAN transformation plan (Figure 8 b) presented and the respective quantification (Table 3) will 
provide an evaluation and programming of restoration actions to be developed in the following research step that will be expected to increase the landscape fire resilience.

The case study was chosen for its representativeness of the Portuguese most affected region by rural fires, with about $67 \%$ of the study area burned in 2017 and dominated mainly by $P p$ and $E g$ (73\% of total area). However, FIRELAN can be replicated anywhere else since its components can be characterized in any circumstance.

Despite the dominance of $P p$ and $E g$ before 2017 fires, according to the application of the model the land suitability area for $E g$ and $P p$ only ranges from $3.2 \%$ in Castanheira de Pera to $10.6 \%$ in Pedrógão Grande, i.e., $6.63 \%$ of total area average. This situation leads to the necessity of a paradigm shift from a mainstream perspective of short-term production landscape management to an ecologically-based landscape planning [90]. This planning requires landscape restoration with a significant increase of native or archaeophytes species, agricultural areas, fuel discontinuities and biodiversity. Edges and swales with ponds, at a more detailed scale, are also useful to reduce the extension of rural fires. The results show that land-use and tree species diversity should change drastically, highlighting the importance of this model implementation towards a new landscape.

Regarding the $72 \%$ transformation actions, $60.7 \%$ of the area should be reserved for low-fuel species, as native or archaeophytes broadleaved trees, and only $5.8 \%$ is suitable for $P p$ and $E g$ plantations. Results show that agriculture can be expanded to $5.4 \%$ of the case study area considered as a fuel discontinuity assumed as a landscape strategy for preventing rural fires [43]. However, in mountainous relief with low fertile soils and without agriculture suitability, the land-use must consider other planning solutions, such as different native trees or shrubs since they can play a crucial role as fire-retardant land-use [91]. According to Pais [92], converting current forests to native oak woodlands as a fire-smart forest strategy, have advantages in reducing fire hazards, increasing the landscape fire resilience and enhancing ecosystem services, such as carbon sequestration and biodiversity.

Regarding the wildland-urban interface, in this case, represented by the settlement buffer areas, the study revealed that from the total area to be converted (1388 ha), 53.8\% are maritime pine and $43.7 \%$ are eucalyptus. This result shows that this flammable forest is still very close to the settlements, providing a high fire risk. The results also revealed a need for transformation actions in Natura 2000 areas where eucalyptus is a precedent land use (25.9\%), supporting the findings of Foresta [93] about eucalyptus expansion inside Natura 2000 sites. Moreover, the model delimitation highlights that the Ecological Network components coincide with $78.7 \%$ of the FIRELAN N area. Since the EN is considered a strategically connected and planned infrastructure rooted at valuable ecosystems, FIRELAN N implementation also ensures soil and water ecosystems improvement, biodiversity and habitats, besides the desired fire resilient characteristics. The benefits of a resilient and sustainable landscape, where the quality of the ecosystems has increased, mean longerterm profitability in what wood production is concerned and ameliorates the quality of produced wood. However, this type of planning provides short-term economic benefits from other woody and non-woody forest products [94] which means the diversification of profitability and the labor force involved.

The comparison with the Regional Forestry Program (PROF) and the Municipal Plan to Protect Forest from Fire (PMDCI) in Figueiró dos Vinhos municipality showed that institutional Plans are insufficient for carrying out FIRELAN model goals and its implementation. Considering the PROF, it has a schematic representation and the ecological corridors only represent the most significant rivers in the study area, in contrast to the FIRELAN components spatially mapped. Relatively to the PMDFCI, it only considers a $100 \mathrm{~m}$ protection buffer around settlements, without planning any specific change to the land-use previous to the fires in 2017. Only the Figueiró dos Vinhos land-use municipal plan shows a better articulation with the FIRELAN proposal, with a clear intention of replacing the current $E g$ forest. However, this intention is still to be implemented and diverge with PROF recommendation of restricting the $E g$ plantation area to $43 \%$, which 
is a very high threshold for a municipal area where the steep relief is a predominant landscape characteristic.

This paper is significant for the Portuguese rural fires planning legal framework because FIRELAN plans, as the proposed land-use plan showed, can give explicit indications of adequate land-uses for fire prevention and sustainability. This is a very significant contribution to solve the problem. This purpose is only possible with the awareness among stakeholders, the creation of infrastructures (tree nurseries, native wood processing industry), the availability of financial instruments and cooperation between stakeholders, including landowners, to motivate them to the landscape transformation advocated in this paper.

The following steps will focus on assessing landscape transformation costs and economic benefits, including ecosystem services payment and validating the proposed model.

The emergence of a restoration-based economy will generate jobs, income and produce goods, besides the environmental and social benefits beyond the financial ones. Furthermore, the improvement of water quality and quantity, fire resilience, soil erosion reduction and biodiversity increasing should be translated into economic benefits, through ecosystem services payment, to public or private landowners.

The model validation is expected to be performed by simulating fire behavior considering the translation of the proposed land uses into fuel models.

\section{Conclusions}

The FIRELAN model is a conceptual and ecologically based GIS model that integrates different principles related to landscape fire resilience and ecological sustainability into a land-use plan, replicable in different landscape contexts. Since fire behavior is linked to the land morphology characteristics (hydrography, slope, solar radiation), the FIRELAN model was designed considering the river basin as a landscape unit. The FIRELAN network is developed along streams/valley bottoms and ridges/hilltops/headwaters functioning as shaded fuel-breaks to contain the perpendicular and the longitudinal fire progression along the hillslope. This network ensures the effectiveness of discontinuities in the landscape with less combustible land-uses, as native broadleaved trees, agriculture or pastures, water elements or void spaces. They also function as a fire-retardant technique and the protection of wildland-urban interface (WUI). The FIRELAN CA includes the remaining areas of the network, and despite their ecological value, are important for a wide variety of land-uses, including fast-growing species (eucalyptus, maritime pine).

The FIRELAN model application to a simplified rural landscape severely damaged by recurrent rural fires from Portugal's center region allowed us to conclude that the rural landscape with similar characteristics (very steep relief with dominance of maritime pine and eucalyptus) has to change. Since about $72 \%$ of the case study area needs transformation actions, it requires a significant increase of native or archaeophytes species, agricultural areas, land discontinuities and the restoration of biodiversity in Natura 2000 areas. In fact, the most flammable species need to decrease from the existent $73 \%$ to a $5.8 \%$ of the total case study area to provide a fire resilient and sustainable landscape. In addition to the importance of creating a compartmentalized and multifunctional landscape, the FIRELAN model also restores the concept of familiar agriculture around settlements. The case study's application showed that a significant part of the buffer areas around settlements does not have adequate land-uses, putting lives at risk. It is also fundamental to focus on the WUI, where the dominant species are maritime pine and eucalyptus, accounting for $54 \%$ and $43.7 \%$, respectively. The EN components are $79 \%$ of the FIRELAN N area, whose implementation ensures soil and water conservation, biodiversity and habitats.

The proposed transformation of the landscape will require a massive mobilization of society to carry it out. Since this area of Portugal has a smallholding, owner's absenteeism and advanced age of those who stayed, the management methods have to go through technical entities' support to local owners and facilitate native forest industry, including exploration, processing and marketing. First of all, this profound transformation requires 
political will, an effort to raise awareness, an enhanced role for the Public Administration at all levels, and the engagement of private agents, landowners and users. The financing will have to go through the institution of payment for ecosystem services to help the owners support the paradigm shift and raise awareness regarding the landscape's ecological functioning.

The FIRELAN model is a sustainable land-use planning solution that can contribute to revising existing Portuguese rural fire planning framework. Therefore, this paper contributes to the discussion and represents an innovation regarding the existent fire prevention models. Further research will include testing FIRELAN applications with fire behavior models, together with the income assessment of products and services provided by the restored ecosystems.

Supplementary Materials: The following are available online at https:/ / www.mdpi.com/article/ 10.3390/su13137055/s1, Table S1: FIRELAN components, area (ha) and percentage of total case study area.

Author Contributions: Conceptualization, M.R.M., N.S.C. and S.B.P.; Formal analysis, M.R.M.; Investigation, M.R.M., N.S.C., S.B.P. and A.M.; Methodology, M.R.M., N.S.C., S.B.P. and A.M.; Project administration, M.R.M. and S.B.P.; Resources, N.S.C., S.B.P. and A.M.; Software, N.S.C. and S.B.P.; Supervision, M.R.M. and S.B.P.; Validation, M.R.M.; Writing-original draft, M.R.M., N.S.C. and S.B.P.; Writing-review \& editing, N.S.C., S.B.P. and A.M. All authors have read and agreed to the published version of the manuscript.

Funding: This work was supported and financed by the Portuguese Foundation for Science and Technology (FCT) under the project SCAPEFIRE PCIF/MOS/0046/2017. This work was also under the research unit Linking Landscape, Environment, Agriculture and Food Research Centre (LEAF) UID/AGR/04129/2020.

Conflicts of Interest: The authors have no conflicts of interest to declare that are relevant to the content of this article.

\section{References}

1. Thom, D.; Taylor, A.R.; Seidl, R.; Thuiller, W.; Wang, J.; Robideau, M.; Keeton, W.S. Forest structure, not climate, is the primary driver of functional diversity in north-eastern North America. Sci. Total Environ. 2021, 762, 143070. [CrossRef] [PubMed]

2. Tran, B.N.; Tanase, M.A.; Bennett, L.T.; Aponte, C. High-severity wildfires in temperate Australian forests have increased in extent and aggregation in recent decades. PLoS ONE 2020, 15, e0242484. [CrossRef]

3. Tedim, F.; Xanthopoulos, G.; Leone, V. Forest Fires in Europe: Facts and Challenges. In Wildfire Hazards, Risks and Disasters, Shroder, J.F., Paton, D., Eds.; Elsevier: Oxford, UK, 2015; pp. 77-99. [CrossRef]

4. Vigna, I.; Besana, A.; Comino, E.; Pezzoli, A. Application of the Socio-Ecological System Framework to Forest Fire Risk Management: A Systematic Literature Review. Sustainability 2021, 13, 2121. [CrossRef]

5. San-Miguel-Ayanz, J.; Moreno, J.M.; Camia, A. Analysis of large fires in European Mediterranean landscapes: Lessons learned and perspectives. For. Ecol. Manag. 2013, 294, 11-22. [CrossRef]

6. EEC. Council Regulation (EEC) No 2158/92 of 23 July 1992 on Protection of the Community's Forests Against Fire. 1992. Available online: https: / / eur-lex.europa.eu/resource.html?uri=cellar:21b27c38-21fb-11e3-8d1c-01aa75ed71a1.0022.01/DOC_1\&format= PDF (accessed on 20 May 2020).

7. EEC. Council Resolution (EEC) No (1999/C 56/01) of 15 December 1998 on a Forestry Strategy for the European Union. 1998. Available online: https:/ / eur-lex.europa.eu/legal-content/EN/TXT/?uri=CELEX:31999Y0226(01) (accessed on 20 January 2020).

8. EC. COM(2006)302 Final. Communication from the Commission to the Council and the European Parliament of 15 June 2006 on an EU Forest Action Plan. 2006. Available online: https://eur-lex.europa.eu/legal-content/EN/TXT/?uri=LEGISSUM\%3Al24277 (accessed on 20 May 2020).

9. EC. A New EU Forest Strategy: For Forests and the Forest-Based Sector. COM (2013) 659. European Commission. Brussels. 2013. Available online: https:/ / eur-lex.europa.eu/resource.html?uri=cellar:21b27c38-21fb-11e3-8d1c-01aa75ed71a1.0022.01/DOC_ $1 \&$ format=PDF (accessed on 20 May 2020).

10. UN. Transforming Our World: The 2030 Agenda for Sustainable Development. 2015. Available online: https://sdgs.un.org/2030 agenda (accessed on 20 May 2020).

11. EC. The European Green Deal. COM (2019) 640 Final. 2019. Available online: https://ec.europa.eu/info/sites/info/files/ european-green-deal-communication_en.pdf (accessed on 20 April 2020). 
12. EC. EU Biodiversity Strategy for 2030. Bringing Nature Back into Our Lives. COM (2020) 380 Final. 2020. Available online: https: / / eur-lex.europa.eu/resource.html?uri=cellar:a3c806a6-9ab3-11ea-9d2d-01aa75ed71a1.0001.02/DOC_1\&format=PDF (accessed on 20 July 2020).

13. Turco, M.; Bedia, J.; Liberto, F.; Fiorucci, P.; Hardenberg, J.; Koutsias, N.; Llasat, M.; Xystrakis, F.; Provenzale, A. Decreasing Fires in Mediterranean Europe. PLoS ONE 2016, 11, e0150663. [CrossRef]

14. Lourenço, L. Forest fires in continental Portugal. Result of profound alterations in society and territorial consequences. Méditerranée 2018. [CrossRef]

15. Mateus, P.; Fernandes, P.M. Forest Fires in Portugal: Dynamics, Causes and Policies. In Forest Context and Policies in Portugal; Reboredo, F., Ed.; World Forests; Springer: Cham, Switzerland, 2014; Chapter IV; Volume 19. [CrossRef]

16. PORDATA Datasource: ICNF/MAAC. 2020. Available online: https://www.pordata.pt/Portugal/Inc\%C3\%AAndios+rurais+e+ \%C3\%A1rea+ardida+\%E2\%80\%93+Continente-1192 (accessed on 20 May 2020).

17. San-Miguel-Ayanz, J.; Durrant, T.; Boca, R.; Libertà, G.; Branco, A.; de Rigo, D.; Ferrari, D.D.; Maianti, P.; Vivancos, T.A.; Schulte, E.; et al. Forest Fires in Europe, Middle East and North Africa 2016; Publications Office: Luxembourg, 2017; ISBN 978-92-79-71292-0. [CrossRef]

18. Beighley, M.; Hyde, A.V. Gestão dos Incêndios Florestais em Portugal numa Nova Era Avaliação dos Riscos de Incêndio, Recursos e Reformas (Portugal Wildfire Management in a New Era). 2018. Available online: https://www.isa.ulisboa.pt/files/cef/pub/ articles/201804/2018_Portugal_Wildfire_Management_in_a_New_Era_Portuguese.pdf (accessed on 20 January 2020).

19. Magalhães, M.R. Para uma Intervenção no Espaço Rural Português in Serrão, A.V. (coord.) Filosofia e Arquitectura da Paisagem; Intervenções; Centro de Filosofia da Universidade de Lisboa: Lisboa, Portugal, 2013; pp. 163-175. ISBN 978-989-8553-20-1.

20. Baptista, O.F. Declínio de um tempo longo (Long time decline). In Agriculturas e Territórios; Celta: Oeiras, Portugal, $2001 ;$ pp. 9-37.

21. Nunes, A.N.; Lourenço, L.; Meira, A.C.C. Exploring spatial patterns and drivers of forest fires in Portugal (1980-2014). Sci. Total Environ. 2016, 573, 1190-1202. [CrossRef] [PubMed]

22. DGT. Land Use and Land Cover Map. 2020. Available online: https://snig.dgterritorio.gov.pt/ (accessed on 20 January 2020).

23. EFFIS. Map of Burned Area from 2018. 2019. Available online: https://effis.jrc.ec.europa.eu/static/effis_current_situation/ public/index.html (accessed on 20 January 2020).

24. Tedim, F.; Leone, V.; McGee, T. Extreme Wildfire Events and Disasters: Root Causes and New Management Strategies; Elsevier: Amsterdam, The Netherlands, 2019; ISBN 9780128157213.

25. Observatório Técnico Independente (OTI). Aprovação dos Planos Regionais de Ordenamento Florestal: Uma Oportunidade Perdida! (Regional Forest Landscape Plans (PROF) Approval: A Lost Opportunity!) Nota informativa 1/2019. Assembleia da República. 2019. Available online: https:/ / www.parlamento.pt/Documents /2019/fevereiro/Nota-Informativa_1-2019_OTI.pdf (accessed on 20 April 2020).

26. PROF Centro Litoral—Portaria n. ${ }^{\circ}$ 56/2019—Diário da República n. ${ }^{\circ}$ 29/2019, Série I de 2019-02-11 2019. Available online: https://dre.pt/application/file/a/119388383 (accessed on 20 April 2020).

27. Walker, B.; Holling, C.S.; Carpenter, S.R.; Kinzig, A. Resilience, adaptability and transformability in social-ecological systems. Ecol. Soc. 2004, 9. Available online: http:/ / www.ecologyandsociety.org/vol9/iss2/art5/ (accessed on 20 June 2020). [CrossRef]

28. Ahern, J. From fail-safe to safe-to-fail: Sustainability and resilience in the new urban world. Landsc. Urban. Plan. 2011, 100, 341-343. [CrossRef]

29. Marey-Perez, M.; Loureiro, X.; Corbelle-Rico, E.J.; Fernández-Filgueira, C. DifferentStrategies for Resilience to Wildfires: The Experience of Collective LandOwnership in Galicia (NorthwestSpain). Sustainability 2021, 13, 4761. [CrossRef]

30. Magalhães, M.R.; Abreu, M.M.; Lousã, M.; Cortez, N. Estrutura Ecológica da Paisagem. In Conceitos e Delimitação-Escalas Regional e Municipal; ISApress: Lisboa, Portugal, 2007.

31. Rothermel, R.C. How to Predict the Spread and Intensity of Forest and Range Fires; Report No. INT-143; Intermountain Forest and Range Experiment Station: Ogden, UT, USA, 1983.

32. Moreira, F.; Duarte, I.; Catry, F.; Acácio, V. Cork extraction as a key factor determining post-fire cork oak survival in a mountain region of southern Portugal. For. Ecol. Manag. 2007, 253, 30-37. [CrossRef]

33. Heyerdahl, E.K.; Brubaker, L.B.; Agee, J.K. Spatial Controls of Historical Fire Regimes: A Multiscale Example from the Interior West, USA. Ecology 2010, 82, 660-678. [CrossRef]

34. Coen, J.L.; Schroeder, W. The High Park Fire: Coupled weather-wildland fire model simulation of a windstorm-driven wildfire in Colorado's Front Range. J. Geophys. Res. Atmos. 2015, 120, 131-146. [CrossRef]

35. Oliveira, S.; Moreira, F.; Boca, R.; San-Miguel-Ayanz, J.; Pereira, J.M.C. Assessment of fire selectivity in relation to land cover and topography: A comparison between Southern European countries. Int. J. Wildland Fire 2014, 23, 620-630. [CrossRef]

36. Viegas, D.X.; Lourenço, L. Os Incêndios Florestais na Região Centro; Revista Sociedade e Território: Porto, Portugal, 1989.

37. Viegas, D.X. Parametric study of Eruptive Fire Behaviour Model. Int. J. Wildland Fire 2006, 15, 169-177. [CrossRef]

38. Dickinson, M.B.; Hutchinson, T.F.; Dietenberger, M.; Matt, F.; Peters, M.P. Litter Species Composition and Topographic Effects on Fuels and Modeled Fire Behavior in an Oak-Hickory Forest in the Eastern USA. PLoS ONE 2016, 11, e0159997. [CrossRef] [PubMed]

39. Calviño-Cancela, M.; Chas-Amil, M.L.; García-Martínez, E.D.; Touza, J. Interacting effects of topography, vegetation, human activities and wildland-urban interfaces on wildfire ignition risk. For. Ecol. Manag. 2017, 397, 10-17. [CrossRef] 
40. Silva, J.S.; Moreira, F.; Vaz, P.; Catry, F.; Godinho-Ferreira, P. Assessing the relative fire proneness of different forest types in Portugal. Plant Biosyst. 2009, 143, 597-608. [CrossRef]

41. Pereira, M.; Aranha, J.; Amraoui, M. Land cover fire proneness in Europe Forest Systems. For. Syst. 2014, 23, 598. [CrossRef]

42. Carmo, M.; Moreira, F.; Casimiro, P.; Vaz, P. Land use and topography influences on wildfire occurrence in northern Portugal. Landsc. Urban. Plan. 2011, 100, 169-176. [CrossRef]

43. Moreira, F.; Vaz, P.; Catry, F.; Silva, J.S. Regional variations in wildfire susceptibility of land-cover types in Portugal: Implications for landscape management to minimize fire hazard. Int. J. Wildland Fire 2009, 18, 563-574. [CrossRef]

44. Povak, N.A.; Hessburg, P.F.; Salter, R.B. Evidence for scale-dependent topographic controls on wildfire spread. Ecosphere 2018, 9, e02443. [CrossRef]

45. Agee, J.K.; Bahro, B.; Finney, M.A.; Omi, P.N.; Sapsis, D.B.; Skinner, C.N.; Wagtendonk, J.W.; Weatherspoon, P.C. The use of shaded fuelbreaks in landscape fire management. For. Ecol. Manag. 2000, 127, 55-66. [CrossRef]

46. Forestry Commission. Building wildfire resilience into forest management planning. In Forestry Commission PraCalvinoctice Guide; Forestry Commission: Edinburgh, UK, 2014; ISBN 978-0-85538-886-7.

47. Mollison, B. Permaculture. A Designers' Manual; Tagari Publications: Sisters Creek, Australia, 1988.

48. Fernández, C.; Vega, J.A.; Jiménez, D.C.S.; Vieira, A.; Merino, A.; Ferreiro, A.; Fonturbel, T. Seeding and mulching+seeding effects on post-fire runoff, soil erosion and species diversity in Galicia (NW Spain). Land Degrad. Dev. 2010, 23, 150-156. [CrossRef]

49. Keizer, J.; Silva, F.C.; Vieira, D.C.S.; González-Pelayo, O.; Campos, I.; Vieira, A.M.D.; Valente, S.; Prats, S.A. The effectiveness of two contrasting mulch application rates to reduce post-fire erosion in a Portuguese eucalypt plantation. Catena 2018, 169, 21-30. [CrossRef]

50. Calviño-Cancela, M.; Chas-Amil, M.L.; García-Martínez, E.D.; Touza, J. Wildfire risk associated with different vegetation types within and outside wildland-urban interfaces. For. Ecol. Manag. 2016, 372, 1-9. [CrossRef]

51. Bento-Gonçalves, A.; Vieira, A. Wildfires in the wildland-urban interface: Key concepts and evaluation methodologies. Sci. Total. Environ. 2020, 707, 1. [CrossRef]

52. Gibbons, P.; Gill, A.M.; Shore, N.; Moritz, M.A.; Dovers, S.; Cary, G.J. Options for reducing house-losses during wildfires without clearing trees and shrubs. Landsc. Urban. Plan. 2018, 174, 10-17. [CrossRef]

53. Badia, A.; Pallares-Barbera, M.; Valldeperas, N.; Gisbert, M. Wildfires in the wildland-urban interface in Catalonia: Vulnerability analysis based on land use and land cover change. Sci. Total. Environ. 2019, 673, 184-196. [CrossRef] [PubMed]

54. Callicott, J.B.; Mumford, K. Ecological Sustainability as a Conservation Concept. Conserv. Biol. 1997, 11, 32-40. [CrossRef]

55. Termorshuizen, J.W.; Opdam, P.; Van den Brink, A. Incorporating ecological sustainability into landscape planning. Landsc. Urban. Plan. 2007, 79, 374-384. [CrossRef]

56. Forman, R.T.T. Land Mosaics: The Ecology of Landscapes and Regions; Cambridge University Press: Cambridge, UK, 1995.

57. Magalhães, M.R. A Arquitectura Paisagista—Morfologia e Complexidade; Editorial Estampa: Lisboa, Portugal, $2001 ;$ p. 525.

58. Cunha, N.S.; Magalhães, M.R. Methodology for mapping the national ecological network to mainland Portugal: A planning tool towards a green infrastructure. Ecol. Indic. 2019, 104, 802-818. [CrossRef]

59. McHarg, I. Design with Nature; John Wiley and Sons: New York, NY, USA, 1967.

60. Ahern, J. Greenways as planning strategy. Landsc. Urban. Plan. 1995, 33, 131-155. [CrossRef]

61. Fabos, J.G. Greenway planning in the United States: Its origins and recent case studies. Landsc. Urban. Plan. 2004, 68, 321-342. [CrossRef]

62. Lennon, M.; Scott, M.; Collier, M.; Foley, K. Developing green infrastructure "thinking": Devising and applying an interactive group-based methodology for practitioners. J. Environ. Plan. Manag. 2015, 59, 843-865. [CrossRef]

63. Liquete, C.; Kleeschulte, S.; Dige, G.; Maes, J.; Grizzetti, B.; Olah, B.; Zulian, G. Mapping green infrastructure based on ecosystem services and ecological networks: A Pan-European case study. Environ. Sci. Policy 2015, 54, 268-280. [CrossRef]

64. Magalhães, M.R. Estrutura Ecológica Nacional-Uma Proposta de Delimitação e Regulamentação; ISApress: Lisboa, Portugal, 2013; ISBN 978-972-8669-53-9.

65. EC. Green Infrastructure (GI)_Enhancing Europe's Natural Capital. COM (2013) 249 Final. 2013. Available online: https: / / eur-lex.europa.eu/legal-content/EN/TXT/?uri=CELEX:52013DC0249 (accessed on 20 May 2020).

66. Čivić, K.; Jones-Walters, L.M. Implementing green infrastructure and ecological networks in europe: Lessons learned and future perspectives. J. Green Eng. 2015, 4, 307-324. [CrossRef]

67. FAO. A Framework for Land Evaluation. FAO Soils Bulletin 32. Rome. ISBN 92-5-100111-1. 1976. Available online: http: //www.fao.org/3/x5310e/x5310e00.htm (accessed on 20 December 2020).

68. Collins, M.G.; Steiner, F.R.; Rushman, M.J. Land-use suitability analysis in the United States: Historical development and promising technological achievements. Environ. Manag. 2001, 28, 611-621. [CrossRef]

69. Magalhães, M.R. Ordem Ecológica e Desenvolvimento. O futuro do território português. In Ecological Order and Development. The Future of Portuguese Territory; ISApress: Lisboa, Portugal, 2016; ISBN 978-972-8669-53-9.

70. ICNF. Cartografia da Perigosidade Estrutural 2020-2030. 2020. Available online: http://www2.icnf.pt/portal/florestas/dfci/ inc/cartografia / cartografia-risco-classes-perigosidade (accessed on 20 June 2020).

71. EFFIS. Map of Burned Area from 2017. 2017. Available online: https://effis.jrc.ec.europa.eu/static/effis_current_situation/ public/index.html (accessed on 20 January 2020). 
72. PMDFCI. Fire Protection Municipal Plan from Figueiró dos Vinhos 3 ${ }^{a}$ Geração (Despachos ns 443A/2018 e 1222B/2018). 2018. Available online: https:/ / fogos.icnf.pt/infoPMDFCI/ (accessed on 20 May 2020).

73. PDM. Land-Use Plan from Figueiró dos Vinhos. 2015. Available online: https://www.dgterritorio.gov.pt/ordenamento/sgt/igtvigor (accessed on 20 May 2020).

74. Magalhães, M.R. The Ecological Structure of Lisbon. Ekistics 1993, 60, 159-166.

75. Cunha, N.S.; Magalhães, M.R.; Domingos, T.; Abreu, M.M.; Withing, K. The land morphology concept and mapping method and its application to mainland Portugal. Geoderma 2018, 325, 72-89. [CrossRef]

76. Silva, J.F.; Cunha, N.; Lopes, A.M.; Abreu, M.M.; Magalhães, M.R. Litoral (Coast). In Estrutura Ecológica Nacional; Magalhães, M.R.M., Ed.; Uma Proposta de Delimitação e Regulamentação (National Ecological Network. A Delimitation and Regulation Proposal); ISAPress: Lisboa, Portugal, 2013; pp. 67-82. ISBN 978-972-8669-53-9.

77. Pena, S.B.; Magalhães, M.R.; Abreu, M.M. Mapping headwater systems using a HS-GIS model. An application to landscape structure and land use planning in Portugal. Land Use Policy 2018, 71, 543-553. [CrossRef]

78. INAG. Hidrografia. (Hydrography). In InterSIG—Gestor de Informação Geográfica; Instituto Nacional da Água; I.P. Agência Portuguesa Ambiente: Lisboa, Portugal, 2010.

79. Cunha, N.S.; Magalhães, M.R.; Domingos, T.; Abreu, M.M.; Küpfer, C. The land morphology approach to flood risk mapping: An application to Portugal. J. Environ. Manag. 2017, 193, 172-187. [CrossRef]

80. Cortez, N. Subsistema Solo (Soil Subsystem). In Estrutura Ecológica da Paisagem; Magalhães, M.R., Abreu, M.M., Lousã, M., Cortez, N., Eds.; Conceitos e Delimitação-Escalas Regional e Municipal (Landscape Ecological Network. Concepts and Delimitation-Regional and Municipal Scales); ISApress: Lisboa, Portugal, 2007.

81. Pena, S.B.; Abreu, M.M.; Magalhães, M.R.; Cortez, N. Water erosion aspects of land degradation neutrality to landscape planning tools at national scale. Geoderma 2020, 363, 114093. [CrossRef]

82. Leitão, M.; Cortez, N.; Pena, S.B. Solo (Soil). In Estrutura Ecológica Nacional; Magalhães, M.R.M., Ed.; Uma Proposta de Delimitação e Regulamentação (National Ecological Network. A Delimitation and Regulation Proposal); ISAPress: Lisboa, Portugal, 2013; pp. 83-104. ISBN 978-972-8669-53-9.

83. Mesquita, S. Vegetação. In Estrutura Ecológica Nacional; Magalhães, M.R.M., Ed.; Uma Proposta de Delimitação e Regulamentação (National Ecological Network. A Delimitation and Regulation Proposal); ISAPress: Lisboa, Portugal, 2013; pp. 105-120. ISBN 978-972-8669-53-9.

84. Moreira, F.; Pe'er, G. Agricultural policy can reduce wildfire. Science 2018, 359, 1001. [CrossRef] [PubMed]

85. Pena, S.B.; Abreu, M.M.; Magalhães, M.R. Planning landscape with water infiltration. Empirical model to assess maximum infiltration areas in Mediterranean Landscapes. Water Resour. Manag. 2016, 30, 2343-2360. [CrossRef]

86. Fu, P.; Rich, P.M. The Solar Analyst 1.0 Manual; Helios Environmental Modeling Institute (HEMI): New York, NY, USA, 2000.

87. Mesquita, S.; Capelo, J. Aptidão Bioclimática às Espécies Arbóreas (Bioclimatic Suitability of tree species). In Ordem Ecológica $e$ Desenvolvimento; Magalhães, M.R., Ed.; O futuro do território português (Ecological Order and Development. The future of Portuguese territory); ISAPress: Lisboa, Portugal, 2016; pp. 63-85. ISBN 978-972-8669-53-9.

88. Molchanov, A.A. Hidrologia Florestal; Fundação Calouste Gulbenkian: Lisboa, Portugal, 1971.

89. FAO. Fire Management: Voluntary Guidelines. Principles and Strategic Actions. Fire Management Working Paper 17. Rome. 2006. Available online: http://www.fao.org/3/j9255e/J9255E00.htm (accessed on 20 December 2020).

90. Magalhães, M.R.; Baptista, F.O.; Cunha, N.; Müller, A.; Pena, S.B.; Silva, J.; Leitão, M. A dimensão humana dos incêndios florestais. In O Ordenamento do Território na Prevenção dos Incêndios Rurais; Tedim, F., Paton, D., Eds.; Estratégias Criativas: Porto, Portugal, 2012; pp. 55-99.

91. Fernandes, P.M. Fire-smart management of forest landscapes in the Mediterranean basin under global change. Landsc. Urban. Plan. 2013, 110, 175-182. [CrossRef]

92. Pais, S.; Aquilué, N.; Campos, J.; Sil, A.; Marcos, B.; Martínez-Freiría, F.; Domínguez, J.; Brotons, L.P.; Honrado, J.P.; Regos, A. Mountain farmland protection and fire-smart management jointly reduce fire hazard and enhance biodiversity and carbon sequestration. Ecosyst. Serv. 2020, 44, 101143. [CrossRef]

93. Foresta, M.; Carranza, M.L.; Garfi, V.; Febbraro, M.D.; Marchetti, M.; Loy, A. A systematic conservation planning approach to fire risk management in Natura 2000 sites. J. Environ. Manag. 2016, 181, 574-581. [CrossRef]

94. Sheppard, J.P.; Chamberlain, J.; Agúndez, D.; Bhattacharya, P.; Chirwa, P.W.; Gontcharov, A.; Sagona, W.C.; She, H.; Tadesse, W.; Mutke, S. Sustainable Forest Management Beyond the Timber-Oriented Status Quo: Transitioning to Co-production of Timber and Non-wood Forest Products-A Global Perspective. For. Manag. 2020, 6, 26-40. [CrossRef] 